\title{
Ontwikkeling en verspreiding van schelpdieren en andere bodemdieren in het sublitoraal van de westelijke Waddenzee in de periode 1992-2017.
}

Auteur(s): $\quad$ Karin Troost, Douwe van den Ende, Margriet van Asch \& Marnix van Stralen

Publicatiedatum: December 2019

Dit onderzoek is uitgevoerd door Wageningen Marine Research in opdracht van en gefinancierd door het Ministerie van Landbouw Natuur en Visserij (LNV), in het kader van het Beleidsondersteunend onderzoekthema 'Themanaam' (projectnummer BO-43-021.02-012)

Wageningen Marine Research Yerseke, November, 2019

VERTROUWELIJK Nee

Wageningen Marine Research rapport C001/20 
Troost, K, D van den Ende, M van Asch \& M van Stralen (2019) Ontwikkeling en verspreiding van schelpdieren en andere bodemdieren in het sublitoraal van de westelijke Waddenzee in de periode 1992-2017. Wageningen Marine Research Wageningen UR (University \& Research centre), Wageningen Marine Research rapport C001/20.

Keywords: Waddenzee, bodemdieren, sublitoraal.

Opdrachtgever: Ministerie van LNV

T.a.v.: Dhr. Angelo Kouwenhoven

Postbus 20401

2500 EK Den Haag

BO-43-021.02-012

Dit rapport is gratis te downloaden van https://doi.org/10.18174/511713

Wageningen Marine Research verstrekt geen gedrukte exemplaren van rapporten.

Wageningen Marine Research Wageningen UR is ISO 9001:2008 gecertificeerd.

(c) 2016 Wageningen Marine Research Wageningen UR

Wageningen Marine Research, onderdeel van Stichting Wageningen Research KvK nr. 09098104,

IMARES BTW nr. NL 8113.83.696.B16. Code BIC/SWIFT address: RABONL2U IBAN code: NL 73 RABO 0373599285
De Directie van Wageningen Marine Research is niet aansprakelijk voor gevolgschade, noch voor schade welke voortvloeit uit toepassingen van de resultaten van werkzaamheden of andere gegevens verkregen van Wageningen Marine Research opdrachtgever vrijwaart Wageningen Marine Research van aanspraken van derden in verband met deze toepassing.

Dit rapport is vervaardigd op verzoek van de opdrachtgever hierboven aangegeven en is zijn eigendom. Niets uit dit rapport mag weergegeven en/of gepubliceerd worden, gefotokopieerd of op enige andere manier gebruikt worden zonder schriftelijke toestemming van de opdrachtgever. 


\section{Inhoud}

$\begin{array}{lr}\text { Samenvatting } & 4\end{array}$

$1 \quad$ Inleiding $\quad 5$

2 Methoden $\quad 5$

2.1 Mosselzaadinventarisatie $\quad 5$

$\begin{array}{lll}2.2 & \text { Uitwerking historische data } & 6\end{array}$

$\begin{array}{lll}2.2 .1 & \text { Gebruikte data } & 6\end{array}$

2.2.2 Bemonsteringsfrequentie 6

$\begin{array}{lll}2.2 .3 \text { Verspreidingskaarten } & 7\end{array}$

$\begin{array}{lll}2.2 .4 & \text { Tijdreeksen } & 9\end{array}$

$\begin{array}{llr}3 & \text { Kaarten en tijdreeksen } & 10\end{array}$

$\begin{array}{llr}3.1 & \text { Mossel (Mytilus edulis) } & 10\end{array}$

3.2 Kokkel (Cerastoderma edule) 13

$\begin{array}{ll}3.3 & \text { Zeester (Asterias rubens) } \\ 3.4 & 16\end{array}$

$\begin{array}{ll}3.4 & \text { Strandgaper (Mya arenaria) } \\ 3.5 & \text { Amerikaanse zwaardschede (Ensis leei) }\end{array}$

$\begin{array}{ll}3.5 & \text { Amerikaanse zwaardschede (Ensis leei) } \\ 3.6 & 21\end{array}$

$\begin{array}{lll}3.6 & \text { Nonnetje (Limecola balthica) } & 23\end{array}$

3.7 Japanse oester (Crassostrea gigas) 26

3.8 Muiltje (Crepidula fornicata) 29

3.9 Strandkrab (Carcinus maenas) $\quad 32$

3.10 Penseel of blaasjeskrab (Hemigrapsus sp.)

$4 \quad$ Discussie en conclusies $\quad 38$

$\begin{array}{lll}4.1 & \text { Ruimtelijke dekking } & 38\end{array}$

$\begin{array}{lll}4.2 & \text { Vangst-efficiëntie } & 38\end{array}$

$\begin{array}{lll}4.3 & \text { Conclusies } & 38\end{array}$

$\begin{array}{lr}\text { Literatuur } & 40\end{array}$

$\begin{array}{lr}\text { Verantwoording } & 41\end{array}$

Bijlage 1. Geregistreerde soorten $\quad 42$ 


\section{Samenvatting}

Sinds 1992 wordt jaarlijks het mosselbestand (Mytilus edulis) in het sublitoraal van de westelijke Waddenzee geïnventariseerd. Daarbij worden naast mosselen ook alle andere aangetroffen soorten schelpdieren geïnventariseerd, alsmede andere grotere ( $>5 \mathrm{~mm}$ ) bodemdiersoorten zoals krabben en zeesterren. Deze inventarisatie is de enige bron van langjarige en gebiedsdekkende informatie over het voorkomen en de verspreiding van bodemdieren in het sublitoraal van de westelijke Waddenzee. Omdat de inventarisatie primair is opgezet ten behoeve van de vergunningverlening voor de mosselzaadvisserij, wordt de informatie over andere soorten dan mosselen niet structureel vastgelegd in de jaarlijkse surveyrapporten. De gegevens zijn wel ingevoerd in de onderliggende databases, en zijn al gebruikt in onderzoek naar de draagkracht van de Waddenzee voor schelpdieren. In 2015 is in het kader van het MEGMA onderzoek (gericht op de ontwikkeling van bodemdieren in de voor mosselzaad- en garnalenvisserij gesloten gebieden in de westelijke Waddenzee) begonnen met de verdere opwerking van deze gegevens met als doel verspreidingskaarten en tijdreeksen van alle geïnventariseerde soorten in het sublitoraal van de westelijke Waddenzee beschikbaar te maken. In voorliggende rapport worden de verspreidingskaarten en tijdreeksen van de tien meest voorkomende soorten gepresenteerd:

- Mossel - Mytilus edulis

- Kokkel - Cerastoderma edule

- Zeester - Asterias rubens

- Strandgaper -Mya arenaria

- Amerikaanse zwaardschede - Ensis leei

- Nonnetje - Limecola balthica

- Muiltje - Crepidula fornicata

- Strandkrab - Carcinus maenas

- Japanse oester - Crassostrea gigas

- Penseel of blaasjeskrab - Hemigrapsus sp. 


\section{Inleiding}

Sinds 1992 wordt jaarlijks het mosselbestand (Mytilus edulis) in het sublitoraal (dus onder de laagwaterlijn) van de westelijke Waddenzee geïnventariseerd in opdracht van de Producentenorganisatie van de Nederlandse Mosselcultuur ("PO Mossel")(Van Stralen et al., 2018a). Daarbij worden naast mosselen ook alle andere aangetroffen soorten schelpdieren geïnventariseerd, alsmede enkele andere grotere bodemdiersoorten zoals krabben en zeesterren ( $>5 \mathrm{~mm}$ ). Deze data zijn uniek, en tot op heden de enige bron met langjarige en gebiedsdekkende informatie over trends en verspreidingspatronen van bodemdieren in het sublitoraal van de westelijke Waddenzee en meer specifiek in de kombergingen Marsdiep en Vliestroom. Omdat de inventarisatie primair is opgezet ten behoeve van de vergunningverlening voor de mosselzaadvisserij, is de informatie over andere soorten dan mosselen niet eerder in rapporten gepresenteerd. In 2015 is binnen het MEGMA onderzoek naar de ontwikkeling van bodemdieren in de voor mosselzaad- en garnalenvisserij gesloten gebieden in de westelijke Waddenzee (Troost et al., 2018, 2019) begonnen met de opwerking van deze gegevens, zodanig dat verspreidingskaarten en tijdreeksen gemaakt konden worden. Binnen MEGMA, waarin de ontwikkeling van bodemdieren in een aantal afgebakende onderzoeksgebieden jaarlijks wordt gemonitord, zijn deze verspreidingskaarten en tijdreeksen van belang als referentie in ruimte en tijd voor waargenomen veranderingen. In voorliggende rapport worden de verspreidingskaarten en tijdreeksen gepresenteerd. Het betreft uitsluitend een presentatie van waargenomen verspreidingspatronen en tijdreeksen, dus zonder verdere analyse van mogelijke verklaringen.

De behandelde soorten zijn de volgende:

- Mossel - Mytilus edulis

- Kokkel - Cerastoderma edule

- Zeester - Asterias rubens

- Strandgaper -Mya arenaria

- Amerikaanse zwaardschede - Ensis leei

- Nonnetje - Limecola balthica

- Muiltje - Crepidula fornicata

- Strandkrab - Carcinus maenas

- Japanse oester - Crassostrea gigas

- Penseel of blaasjeskrab - Hemigrapsus sp.

\section{Methoden}

\subsection{Mosselzaadinventarisatie}

Sinds 1992 wordt tweemaal per jaar (najaar en voorjaar) het mosselbestand in het sublitoraal van de westelijke Waddenzee geïnventariseerd. De survey in het najaar is gericht op de vergunningverlening voor de najaarsvisserij op als instabiel liggend beschouwd mosselzaad. Tijdens de najaarssurvey wordt gevist met een mosselkor. Op basis van de daarmee behaalde vangsten wordt de ligging van de nieuwe zaadbanken ingetekend en worden, uitgaande van de vangstvolumes op basis van expert judgement, bestandsschattingen gemaakt. Deze survey is dus van kwalitatieve aard (Van Stralen et al., 2018a). Bij de survey in het voorjaar worden bodemmonsters genomen. De daarin aanwezige bodemdieren worden geteld en gewogen en vervolgens omgerekend naar dichtheden en bestandsgroottes (Van Stralen et al., 2018b). De voorjaarssurvey is dus meer kwantitatief van aard. Het onderzoeksgebied betreft de kombergingen Vliestroom en Marsdiep. Daarnaast is ook incidenteel gemonsterd in komberging Eierlandse gat, in de Zoutkamperlaag en Eems, waar slechts zelden sublitorale mosselbanken worden gesignaleerd. 
De bemonstering in het voorjaar vind plaats volgens een gestratificeerd monstergrid. Dit houdt in dat in de gebieden waar mosselen worden verwacht (op basis van de najaarssurvey, survey gegevens uit eerdere jaren, en informatie van de Wadden Unit (LNV) en (garnalen)vissers) de monsterpunten dichter bij elkaar gelegd worden. Het hele gebied wordt daarvoor eerst opgedeeld in afzonderlijke "strata" en vervolgens worden binnen deze strata monsterpunten gelegd. De monsterdichtheid in strata waarin mosselen verwacht worden is daarbij hoger dan in strata waar minder of geen mosselen verwacht worden. Uitgangspunt bij het opstellen van het monsterprogramma is een standaardgrid van $500 \times 500 \mathrm{~m}$ dat wordt uitgedund of verdicht, afhankelijk van de ligging van de mosselbanken en het maximaal aantal stations dat binnen de beschikbare (vaar)tijd (4 weken) kan worden bemonsterd (ca. 600). Omdat de mossel de doelsoort is en het voorkomen van mosselbanken van jaar tot jaar verschilt, verschilt ook de ligging van het grid van jaar tot jaar. Dit betekent dat op de plekken waar vaker mosselzaad voorkomt ook vaker gemonsterd is.

$\mathrm{Er}$ is gemonsterd met een aangepaste zuigkor, met een mesbreedte van $20 \mathrm{~cm}$. Op ieder monsterpunt wordt gesleept over een afstand van ca. $150 \mathrm{~m}$. Locaties dieper dan 10 meter zijn bemonsterd met een vergelijkbaar vistuig dat wordt voortgesleept aan een draad (bodemschaaf). Tijdens de bemonstering is gebruik gemaakt van DGPS-apparatuur van het schip voor positie en afstandsbepaling. Voor afstandsbepaling bij het monstername met de schaaf is gebruik gemaakt van een loopwiel met teller. Voor verdere details zie Van Stralen et al. (2018b).

De monsters zijn aan dek opgevangen en gespoeld over een $5 \mathrm{~mm}$ zeef. Bij grote vangsten is een deelmonster genomen op basis van volume. Uit (sub)monsters zijn alle levende schelpdieren (incl. krabben en zeesterren) verzameld, ontdaan van aangroei en gesorteerd op leeftijd en grootte. De onbeschadigde dieren zijn vervolgens per klasse geteld en gewogen (levend "natgewicht", ofwel "natgewicht", incl. schelp). Kapotte dieren zijn alleen geteld per grootteklasse. In de verdere berekeningen is aangenomen dat deze dieren hetzelfde individuele gewicht hadden als nog wel intacte dieren in het monster. Om te voorkomen dat kapotte dieren dubbel worden geteld, zijn van de kapotte schelpdieren alleen de stukken waar een slotje aan zit geteld. De verzamelde data zijn opgeslagen in een centrale database. Zie verder Van Stralen et al. (2018b).

\subsection{Uitwerking historische data}

\subsubsection{Gebruikte data}

Voor het maken van verspreidingskaarten en tijdreeksen is gebruik gemaakt van de gegevens uit de voorjaarssurveys van 1992 tot en met 2017. Op de data zijn eerst datachecks uitgevoerd, door controle op afwijkende aantallen, totaalgewichten, individuele gewichten en soortnamen. Onderdeel van deze datachecks was ook het per soort vaststellen in welke jaren deze systematisch geregistreerd is. Bij aanvang van de inventarisatie in 1992 richtte deze zich op soorten die van belang waren voor schelpdiervisserij in de Waddenzee (mossel, kokkel, zeester als belangrijke predator en zeepok als ongewenste aangroei bij levering van de mosselen). Later zijn daar andere soorten aan toegevoegd. Omwille van het in de hand houden van de verwerkingstijd van de monsters aan boord is in de begin jaren een aantal soorten soms ook weer buiten beschouwing gelaten. Voor de 10 soorten waarvan in dit rapport kaarten zijn gemaakt is in Tabel 1 aangegeven in welke jaren ze zijn geregistreerd. In Tabel 2 in Bijlage 1 is deze informatie voor alle soorten weergegeven zoals die tijdens de survey structureel geregistreerd worden.

\subsubsection{Bemonsteringsfrequentie}

In Figuur 1 is weergegeven hoe vaak de stations in de periode 1992-2017 zijn bemonsterd. Door de wijze van stratificeren zijn de stations in gebieden waar mosselbanken vaker voorkomen relatief vaak bemonsterd. Deze kaart kan in die zin al als verpreidingskaart voor mosselen worden gezien, maar dan niet gebaseerd op de metingen maar op de verwachtingen over het voorkomen van mosselen voorafgaand aan de surveys. 
Tabel 1: Per soort het jaar waarin de soort voor het eerst is bemonsterd of voor het eerst is aangetroffen $\left(^{*}\right)$ in de sublitorale mosselsurvey. Daarnaast de jaren dat de soort niet mee is genomen in de survey.

\begin{tabular}{llll}
\hline Soort (Nederlandse naam) & Latijnse naam & vanaf & niet in \\
\hline Mossel & Mytilus edulis & 1992 & \\
Kokkel & Cerastoderma edule & 1992 & \\
Zeester & Asterias rubens & 1992 & \\
Strandgaper & Mya arenaria & 1993 & 1995 en 1996 \\
Amerikaanse zwaardschede & Ensis leei & 1993 & 1995 en 1996 \\
Nonnetje & Limecola balthica & 1993 & 1995 en 1996 \\
Muiltje & Crepidula fornicata & $2001^{*}$ & \\
Strandkrab & Carcinus maenas & 2001 & \\
Japanse oester & Crassostrea (of Magallana) gigas & $2005^{*}$ & \\
Penseel- en blaasjeskrab & Hemigrapsus sp. & $2009^{*}$ & \\
\hline
\end{tabular}

\subsubsection{Verspreidingskaarten}

Het voordeel van het gebruik van een gestratificeerd monstergrid is dat de betrouwbaarheid van bestandsschattingen voor mosselen wordt vergroot zonder de onderzoeksinspanning te vergroten. Een nadeel is dat bij het maken van verspreidingskaarten de gegevens per station niet eenvoudigweg kunnen worden uitgemiddeld omdat de stations niet elk jaar zijn bemonsterd en de stations met een hogere frequentie zijn bemonsterd in jaren dat daar mosselen werden verwacht. Dit heeft geleid tot een verschillende aanpak bij het maken van de kaarten voor mosselen en voor de overige soorten, zoals in de volgende paragraaf wordt toegelicht. Voor soorten die in relatief hoge dichtheden en/of algemeen voorkomen en waarvan op de meeste monsterpunten vaak wel enkele exemplaren gevonden worden, is bij het maken van de kaarten uitgegaan van een ondergrens van 5 individuen per $\mathrm{m}^{2}$.

\section{Verspreidingsgebied}

De kans op aantreffen van mosselen is in Figuur 2 is weergegeven als het aantal keren in de periode 1992-2017 dat mosselen in dichtheden van meer dan 5 mosselen per $\mathrm{m}^{2}$ zijn aangetroffen. De reden waarom is gekozen voor weergave van het aantal keren dat mosselen zijn aangetroffen en niet voor de frequentie van aantreffen per monsterpunt (percentage van het aantal keer aanwezig gedeeld door het aantal keer bemonsterd) is de volgende. In jaren waarin op bepaalde monsterpunten geen mosselen werden verwacht zijn deze niet altijd bemonsterd. Wanneer een percentage berekend zou worden missen er dus jaren waarin op het betreffende punt géén mosselen aangetroffen zouden zijn. Daarmee zou de frequentie van aantreffen overschat worden. Stel bijvoorbeeld dat in de periode $1992-2017$ (=25 jaar) een station 20 keer is bemonsterd en dat daarbij 15 keer mosselen zijn aangetroffen. De trefkans van mosselen, berekend als het aantal keer "raak" gedeeld door het aantal keer dat het betreffende station is bemonsterd is in dit geval 15/20 =75\%. De trefkans wordt daarmee overschat omdat van de jaren dat op stations geen mosselen werden verwacht het station niet alle jaren (in dit voorbeeld 5 keer niet jaar) is bemonsterd. Daarbij is de aanname dat in de jaren dat het station niet bemonsterd is er ook geen mosselen aanwezig waren. Een oplossing zou kunnen zijn om het percentage niet te berekenen over alle jaren waarin een station bemonsterd is, maar over alle jaren. In het voorbeeld zou de trefkans dan berekend worden als 15/25 $=60 \%$. Om aannames te vermijden en zo dicht mogelijk bij de onderliggende data te blijven is ervoor gekozen om voor mosselen geen percentages te presenteren maar puur het aantal keren dat mosselen zijn aangetroffen. 


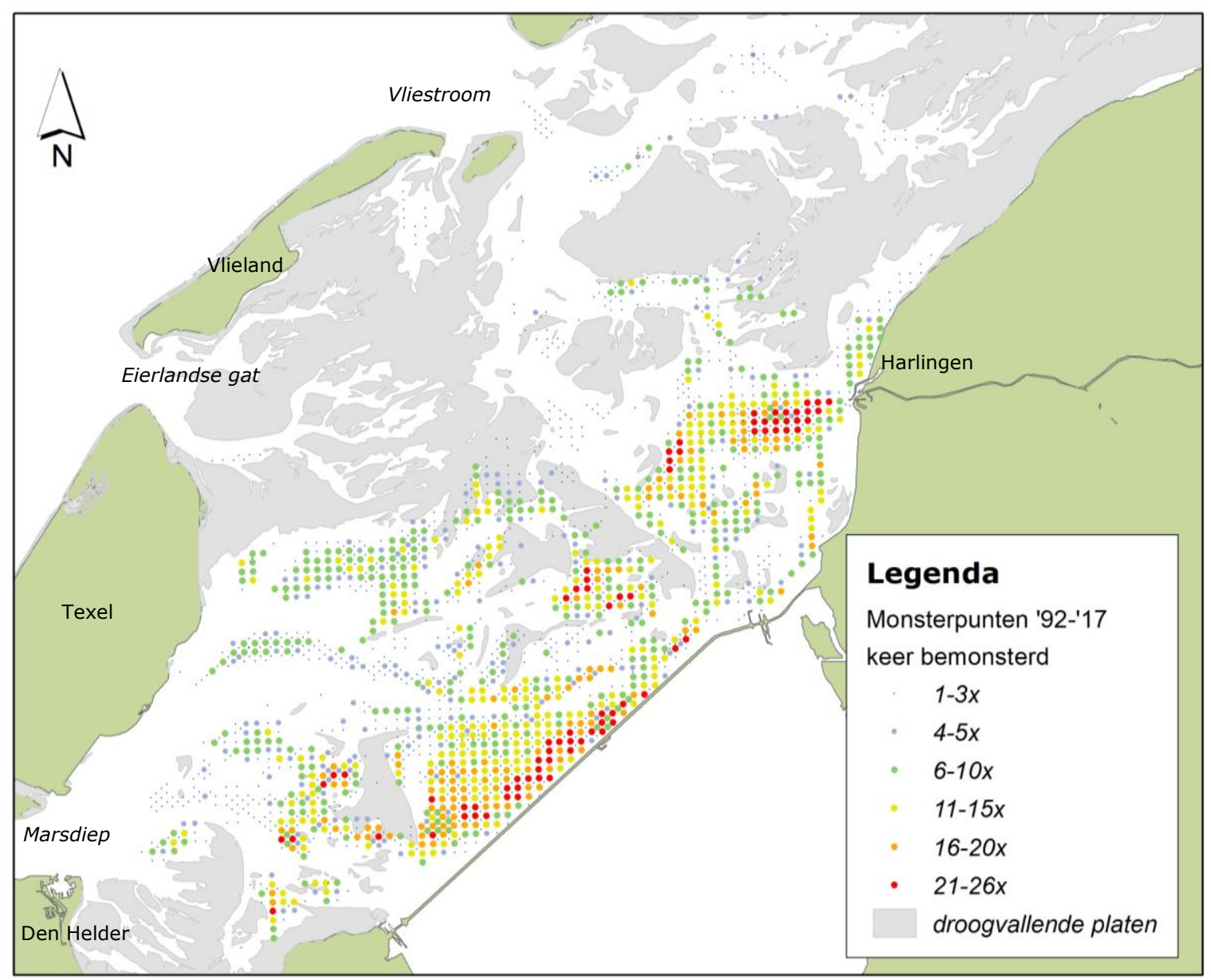

Figuur 1: De frequentie waarmee monsterpunten in de sublitorale mosselzaadsurvey zijn bemonsterd in de periode $1992-2017$.

Het verschil in de analyse van de mosseldata en die van de overige soorten is dat het monstergrid in de surveys niet op verwachtingen over andere soorten dan mosselen wordt gestratificeerd. Voor de overige soorten leidt het berekenen van de frequentie van aantreffen (percentage van het aantal keer aanwezig gedeeld door het aantal keer bemonsterd) niet tot een overschatting, voor zover het voorkomen van deze soorten niet is gekoppeld aan het voorkomen van mosselen. Van de soorten die in dit rapport worden gepresenteerd geldt dit laatste met name voor soorten die voorkomen op hard substraat en daarvoor ook mosselen gebruiken (muiltjes) en in mindere mate voor soorten met een voorkeur hebben voor het mosselhabitat maar ook buiten mosselbanken algemeen voorkomen (krabben en zeesterren).

Omdat voor de overige soorten de trefkans wordt uitgedrukt als percentage van het aantal keer dat betreffend monsterpunt is bemonsterd, zijn monsterpunten die minder dan vier keer zijn bemonsterd niet in de analyse meegenomen en dus ook niet weergegeven in de verspreidingskaarten.

\section{Gemiddelde dichtheden}

De frequentiekaarten geven nog geen inzicht geven in hoe talrijk de verschillende soorten voorkomen. Per soort is daarom ook een kaart gemaakt met daarin per monsterpunt de gemiddelde dichtheid in aantallen per $\mathrm{m}^{2}$, berekend over de jaren dat dit monsterpunt bemonsterd is. Omdat de verschillende frequenties waarmee monsterpunten bemonsterd zijn kunnen leiden tot een vertekend beeld is middels kleuren onderscheid gemaakt tussen enkele categorieën van bemonsteringsfrequentie. Zo kan de lezer beter inschatten of hoge gemiddelden over meerdere jaren zijn waargenomen, of dat het waarschijnlijker om een incidentele waarneming gaat. In de kaarten zijn de gemiddelde dichtheden voor alle stations van het $500 \times 500$ m basisgrid weergegeven, dus ook van de stations die 1, 2 of 3 keer zijn bemonsterd. 


\subsubsection{Tijdreeksen}

Voor iedere soort is per jaar het totale bestand berekend zoals dat ook voor mosselen tijdens de jaarlijks bestandsopnamen wordt gedaan. Dit houdt in dat per jaar het bestand in miljoenen individuen en miljoen $\mathrm{kg}$ natgewicht (incl. schelp) is berekend volgens de in dat jaar geldende stratificering van de monsterpunten. Zie voor meer uitleg Van Stralen et al. (2018b), Van Asch et al. (2018) en Perdon et al. (2018). Door deze gegevens in de tijd uit te zetten wordt inzichtelijk hoe de bestanden van de diverse soorten schelpdieren en andere bodemdieren zich hebben ontwikkeld. 


\section{Kaarten en tijdreeksen}

In dit hoofdstuk worden per soort verspreidingskaarten en tijdreeksen gepresenteerd, zonder deze verder te beschrijven, interpreteren of verklaren.

\subsection{Mossel (Mytilus edulis)}

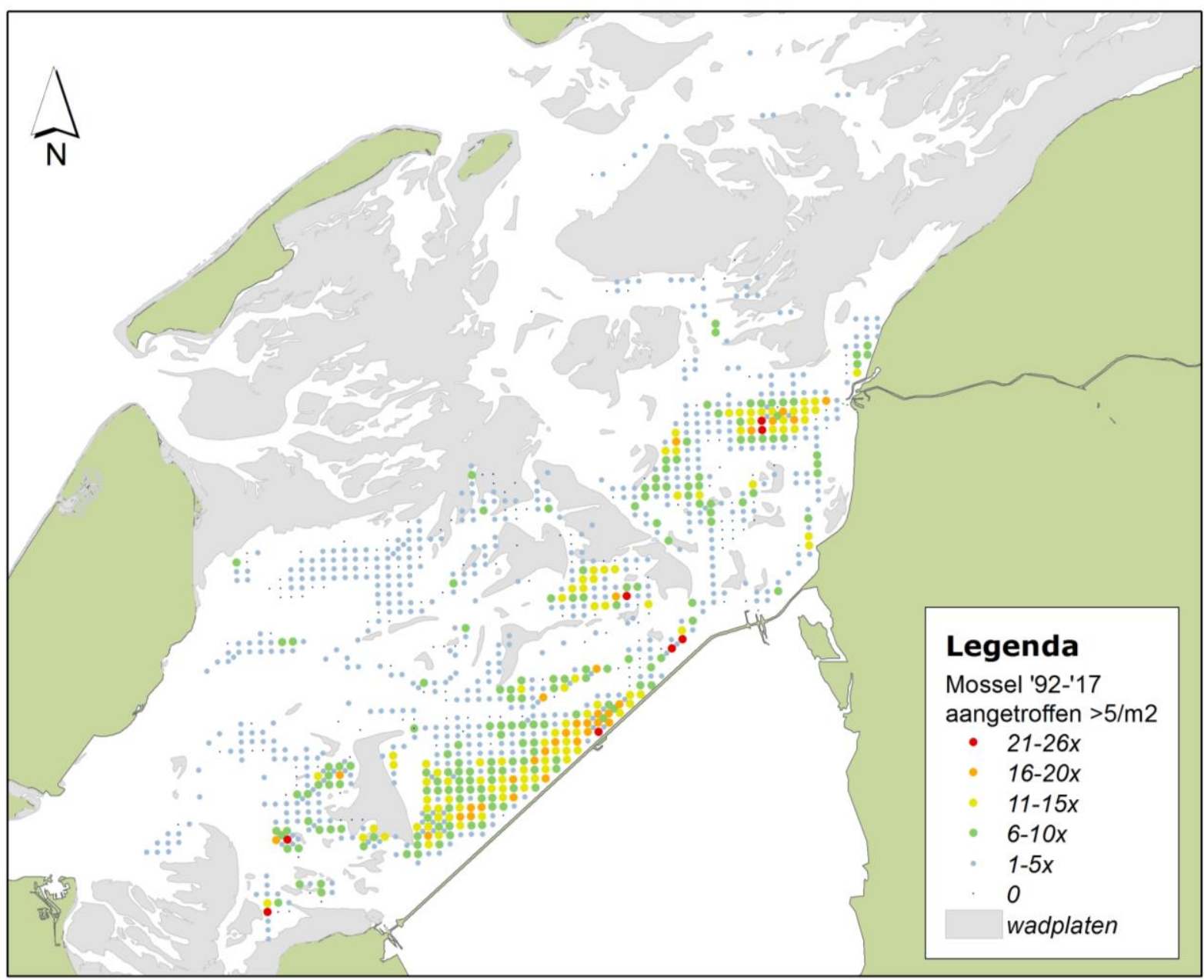

Figuur 2. Verspreiding van mosselen in het sublitoraal van de westelijke Waddenzee, uitgedrukt als het aantal keren dat mosselen zijn aangetroffen in een dichtheid van meer dan 5 per $\mathbf{m}^{\mathbf{2}}$ in de periode 1992-2017. Monsterpunten die minder dan $4 x$ bemonsterd zijn, zijn niet weergegeven. 


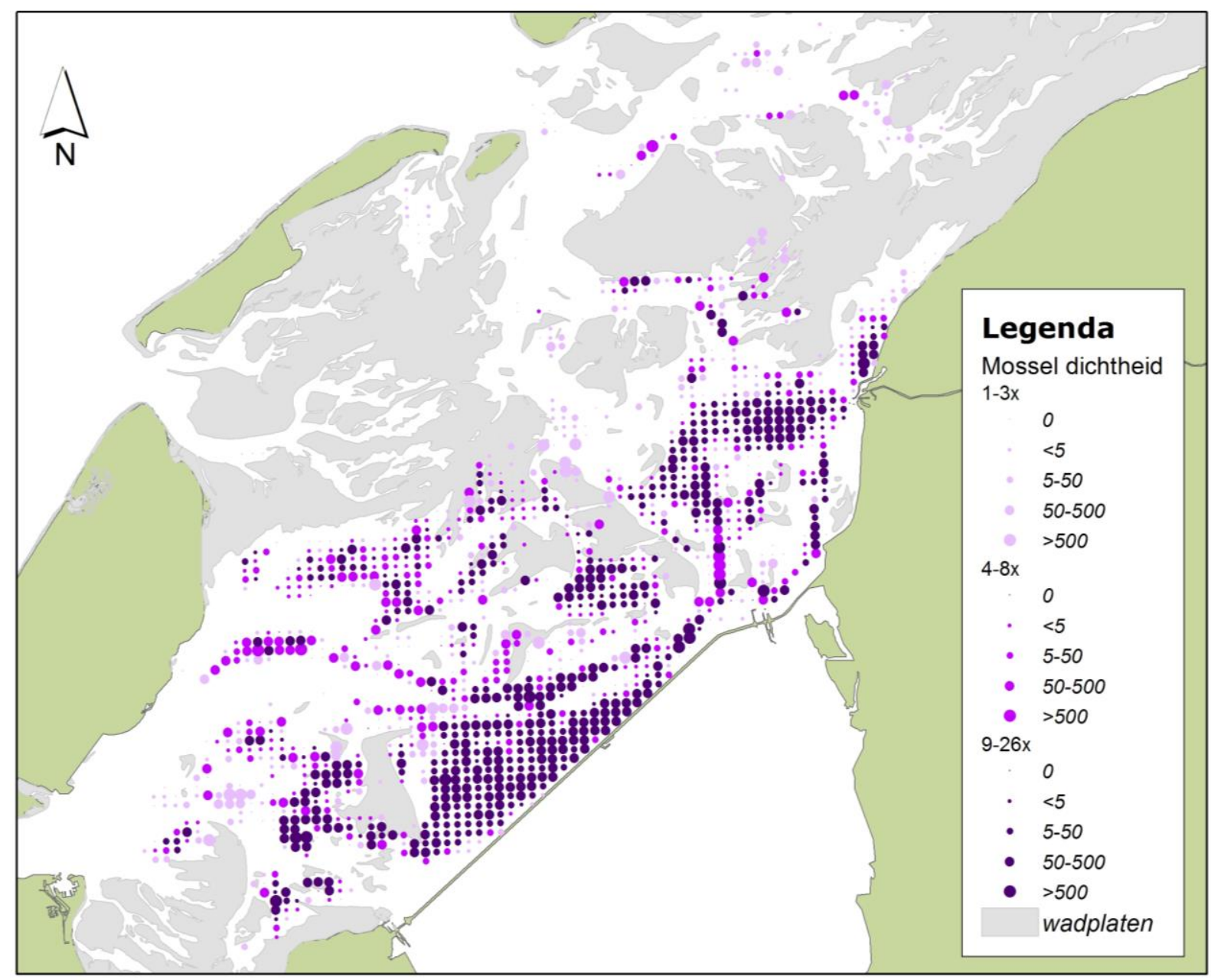

Figuur 3. Gemiddelde dichtheid van mosselen (aantal per $\mathrm{m}^{2}$ ) in het sublitoraal van de westelijke Waddenzee, berekend over alle jaren waarin een monsterpunt bemonsterd is in de periode 19922017, opgedeeld in drie categorieën van bemonsteringsfrequentie (1-3x, 4-8x en 9-26x bemonsterd). 


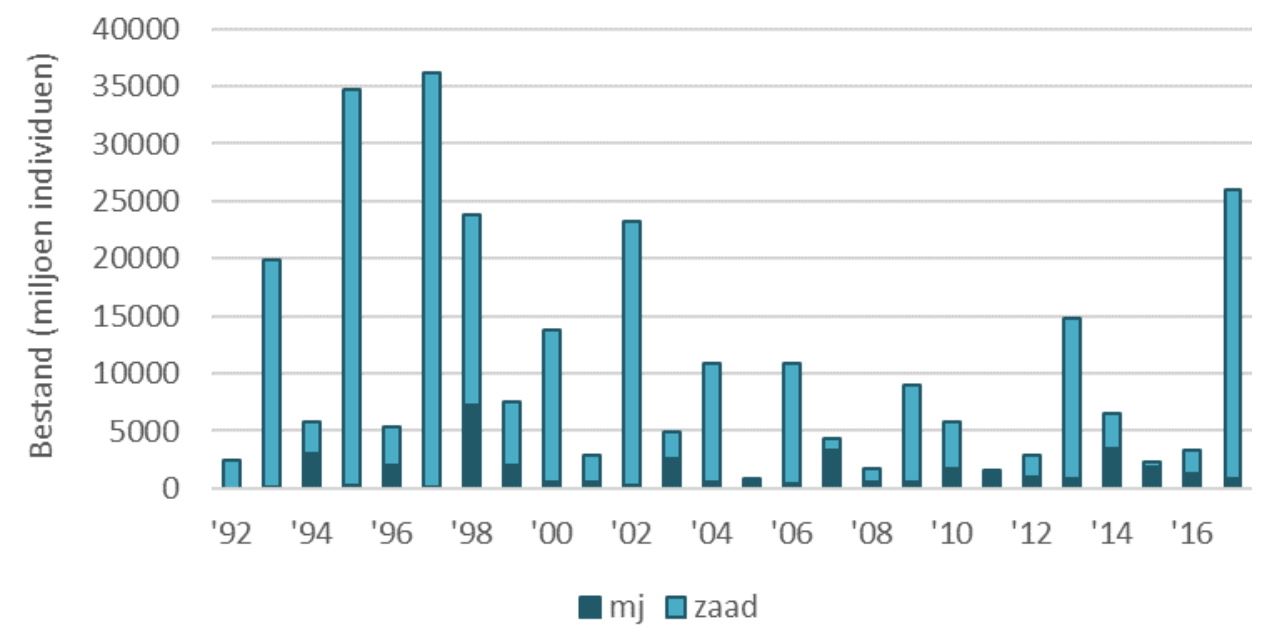

Figuur 4: Het bestand aan mosselen (in miljoen individuen) in de periode 1992 - 2017.

Onderscheid is gemaakt tussen meerjarige mosselen en mosselzaad (dat één winter heeft overleefd).

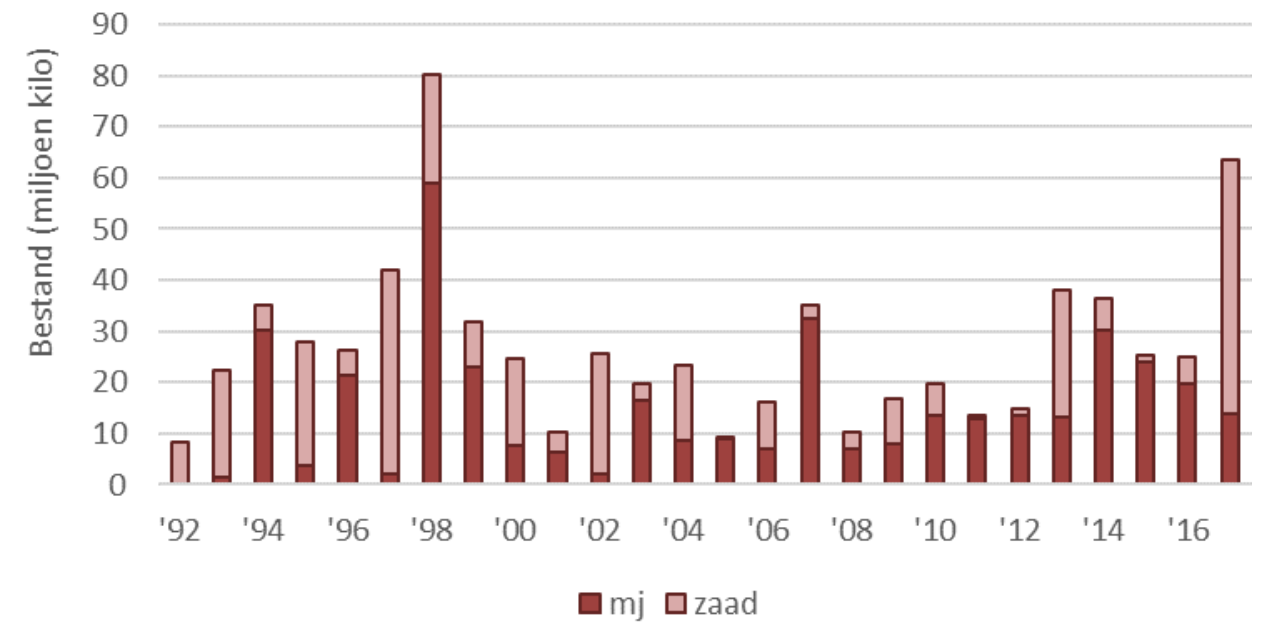

Figuur 5: Het bestand aan mosselen (in miljoen kilogram natgewicht incl. schelp) in de periode 1992 - 2017. Onderscheid is gemaakt tussen meerjarige mosselen en mosselzaad (dat één winter heeft overleefd). 


\subsection{Kokkel (Cerastoderma edule)}

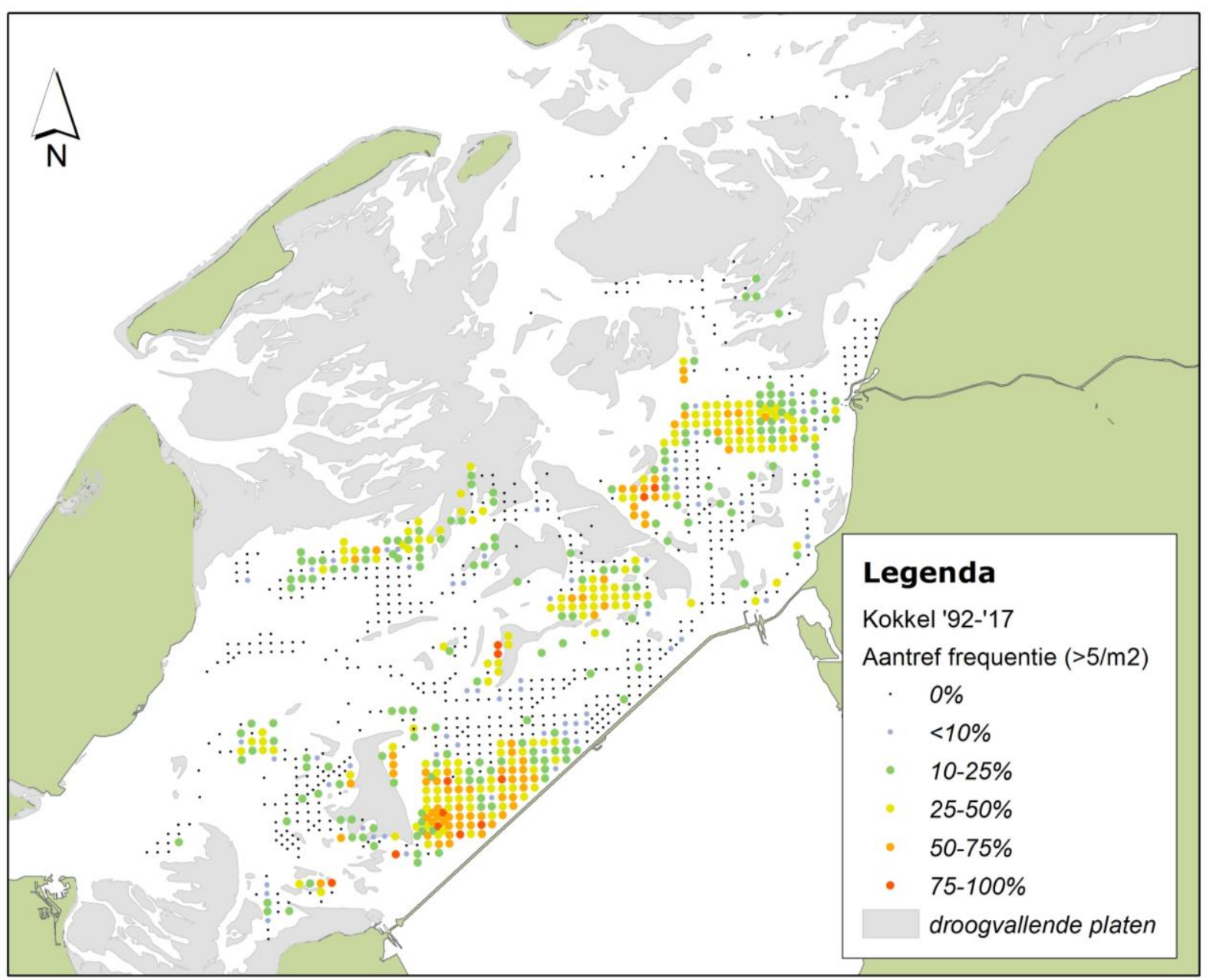

Figuur 6. Verspreiding van kokkels in het sublitoraal van de westelijke Waddenzee, uitgedrukt als de frequentie van aantreffen van dichtheden groter dan 5 per $\mathbf{m}^{2}$ in de periode 1992-2017. Monsterpunten die minder dan $4 x$ bemonsterd zijn, zijn niet weergegeven. 


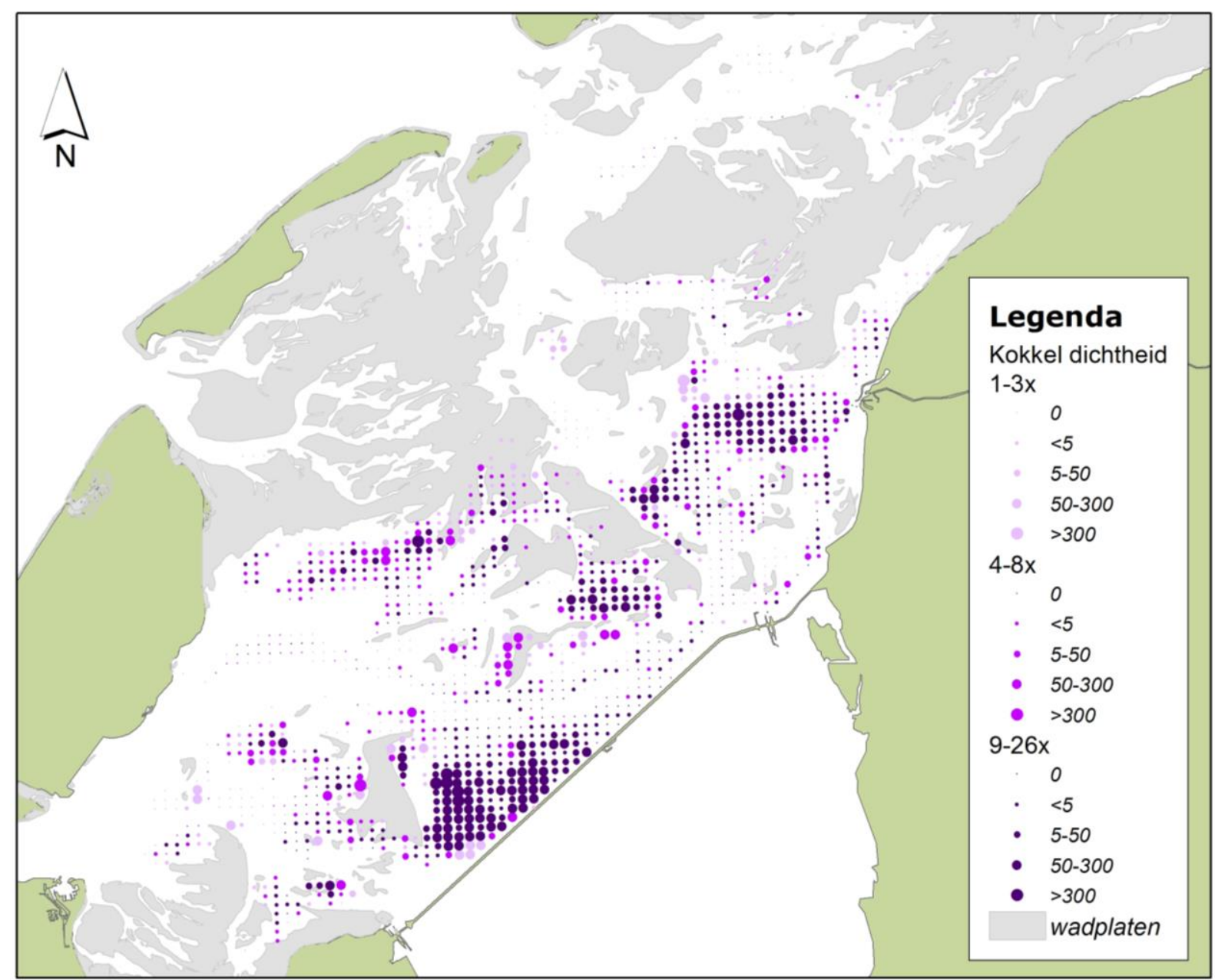

Figuur 7. Gemiddelde dichtheid van kokkels (aantal per $\mathrm{m}^{2}$ ) in het sublitoraal van de westelijke Waddenzee, berekend over alle jaren waarin een monsterpunt bemonsterd is in de periode 19922017, opgedeeld in drie categorieën van bemonsteringsfrequentie (1-3x, 4-8x en 9-26x bemonsterd). 


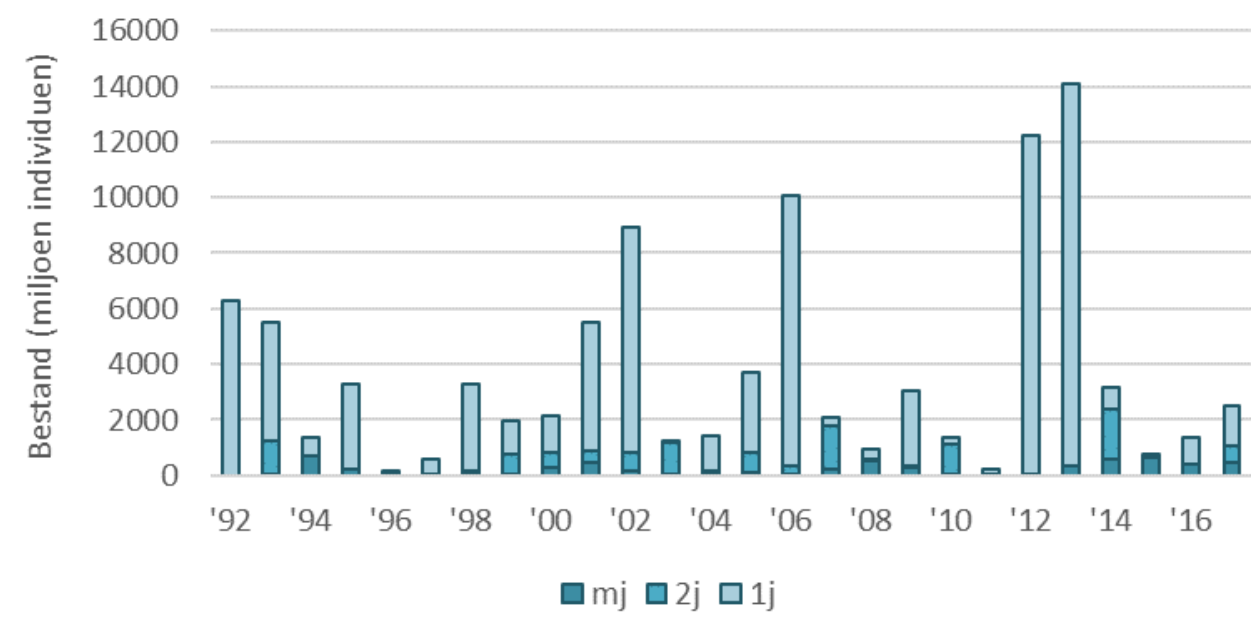

Figuur 8: Het bestand aan kokkels (in miljoen individuen) in de periode 1992 - 2017. Onderscheid is gemaakt tussen drie verschillende jaarklassen: 1-jarig, 2-jarig en meerjarig (3 jaar en ouder).

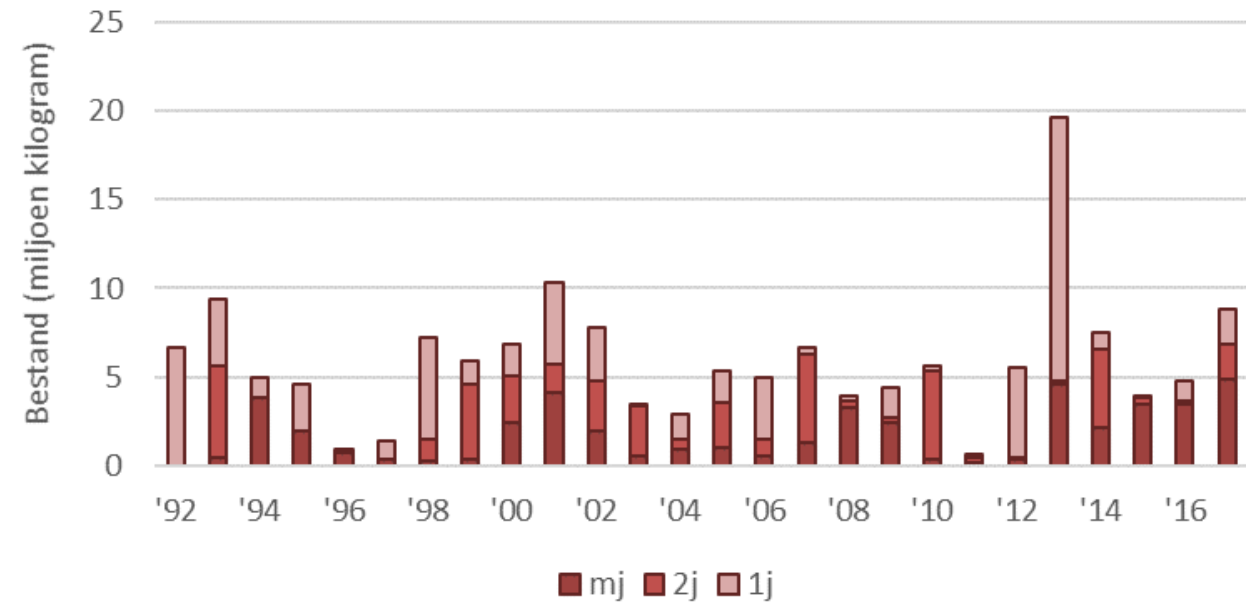

Figuur 9: Het bestand aan kokkels (in miljoen kilogram natgewicht incl. schelp) in de periode 1992 - 2017. Onderscheid is gemaakt tussen drie verschillende jaarklassen: 1-jarig, 2-jarig en meerjarig (3 jaar en ouder). 


\subsection{Zeester (Asterias rubens)}

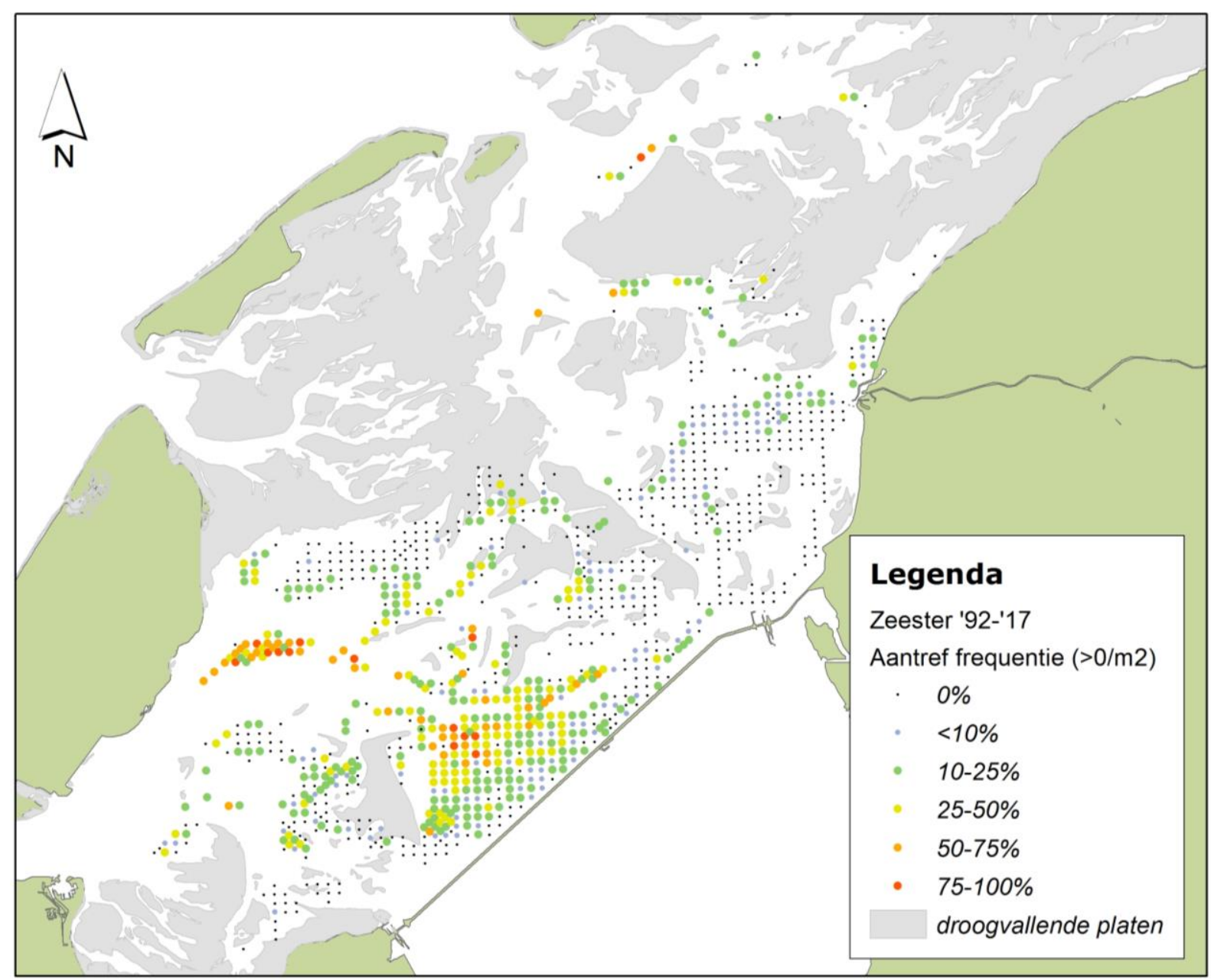

Figuur 10. Verspreiding van zeesterren in het sublitoraal van de westelijke Waddenzee, uitgedrukt als de frequentie van aantreffen (dichtheden groter dan 0 per $\mathrm{m}^{2}$ ) in de periode 1992-2017. Monsterpunten die minder dan $4 x$ bemonsterd zijn, zijn niet weergegeven. 


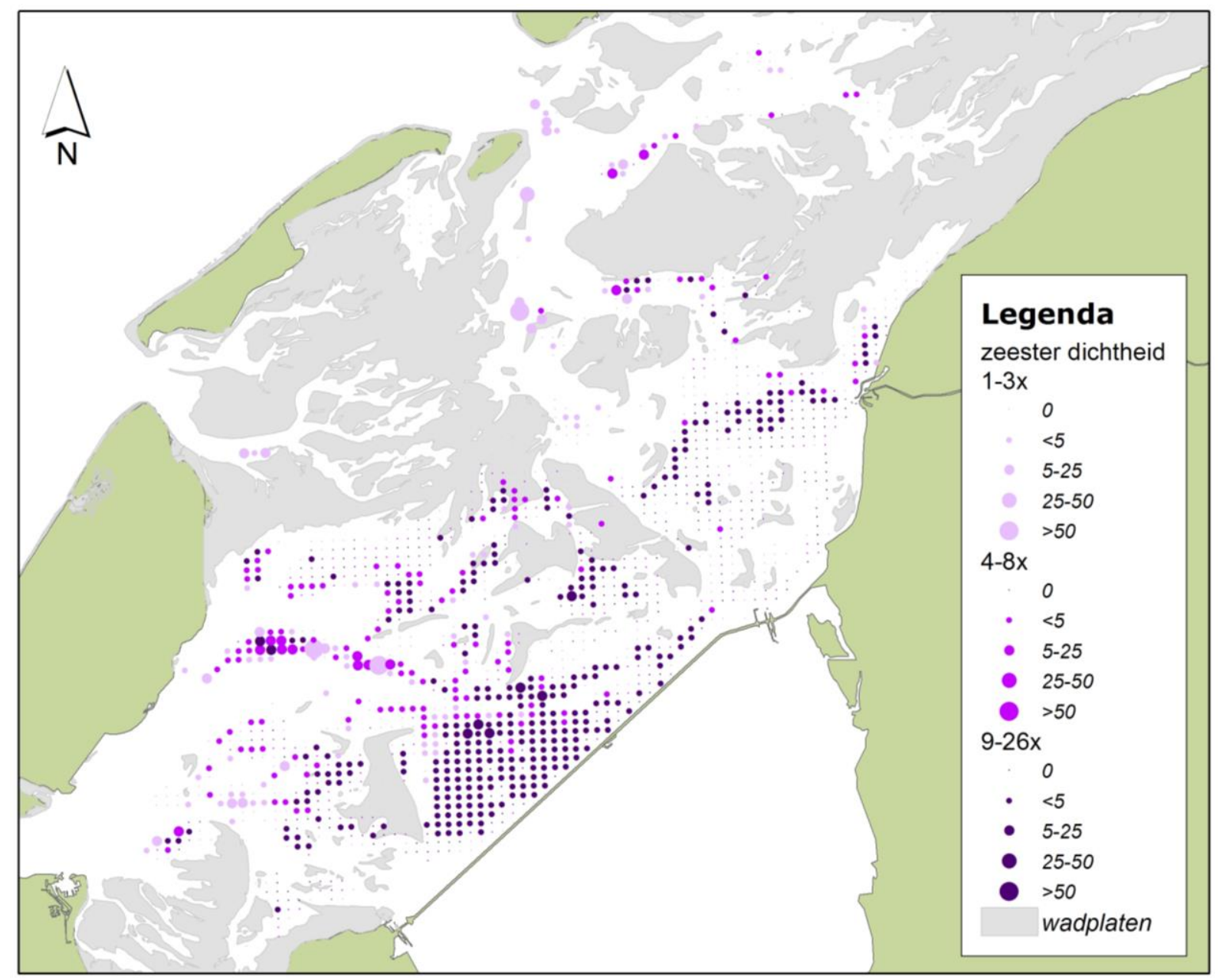

Figuur 11. Gemiddelde dichtheid van zeesterren (aantal per $\mathrm{m}^{2}$ ) in het sublitoraal van de westelijke Waddenzee, berekend over alle jaren waarin een monsterpunt bemonsterd is in de periode 19922017, opgedeeld in drie categorieën van bemonsteringsfrequentie (1-3x, 4-8x en 9-26x bemonsterd). 


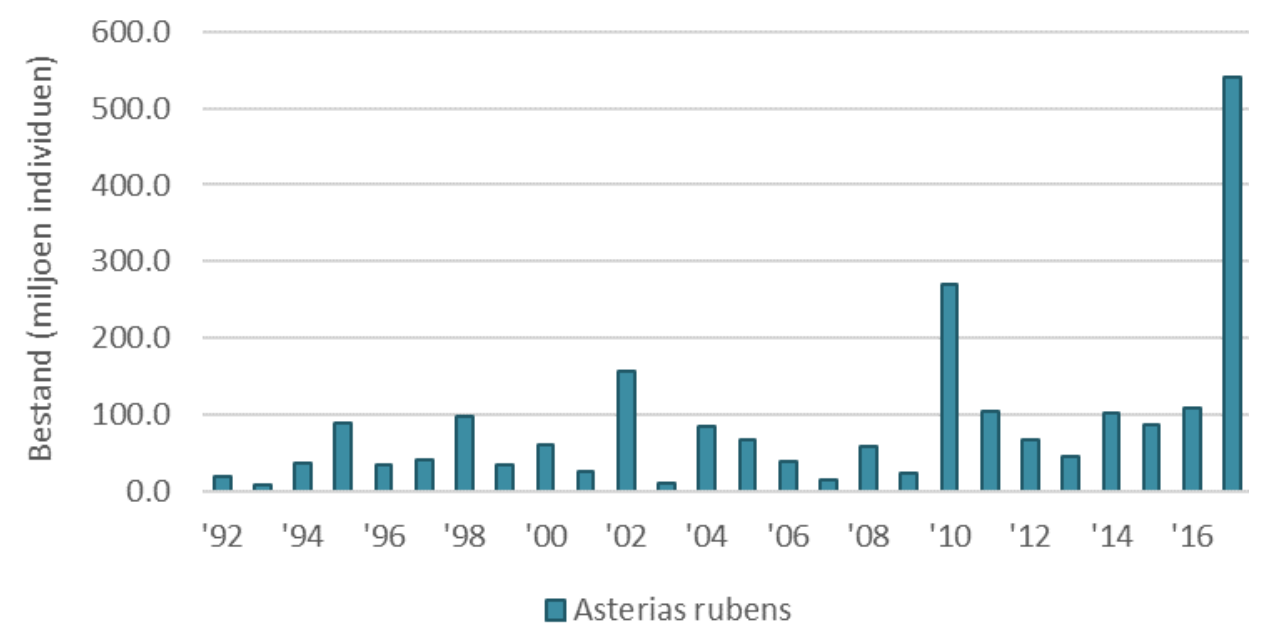

Figuur 12: Het bestand aan zeesterren (in miljoen individuen) in de periode 1992 - 2017.

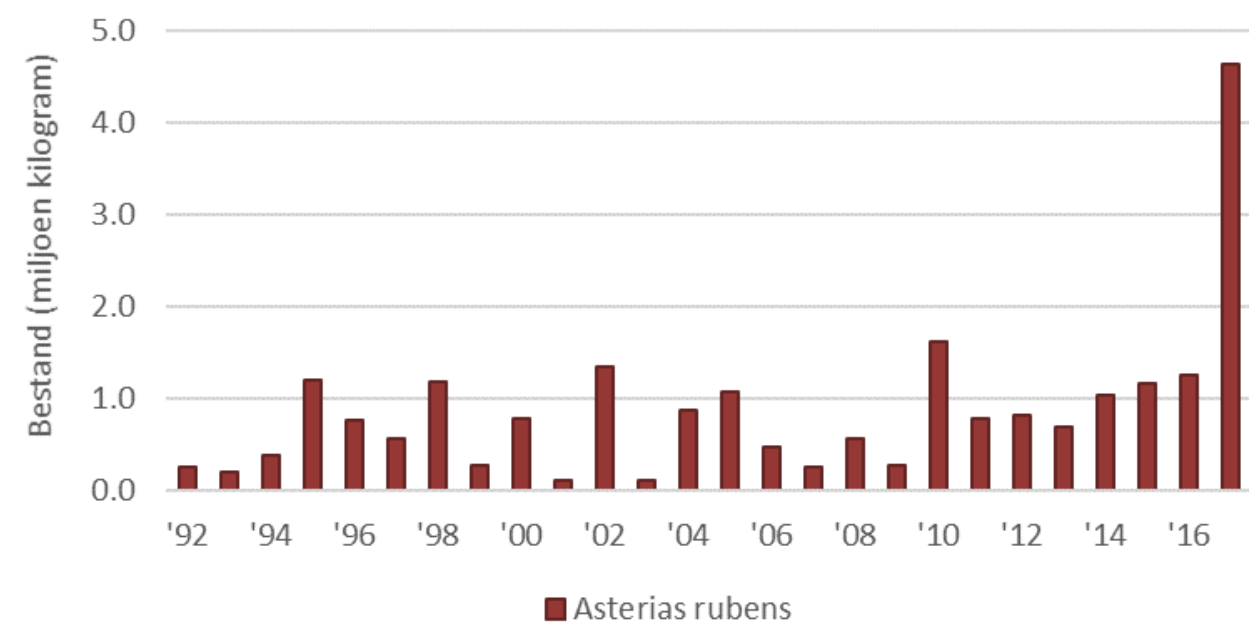

Figuur 13: Het bestand aan zeesterren (in miljoen kilo natgewicht) in de periode 1992 - 2017. 


\subsection{Strandgaper (Mya arenaria)}

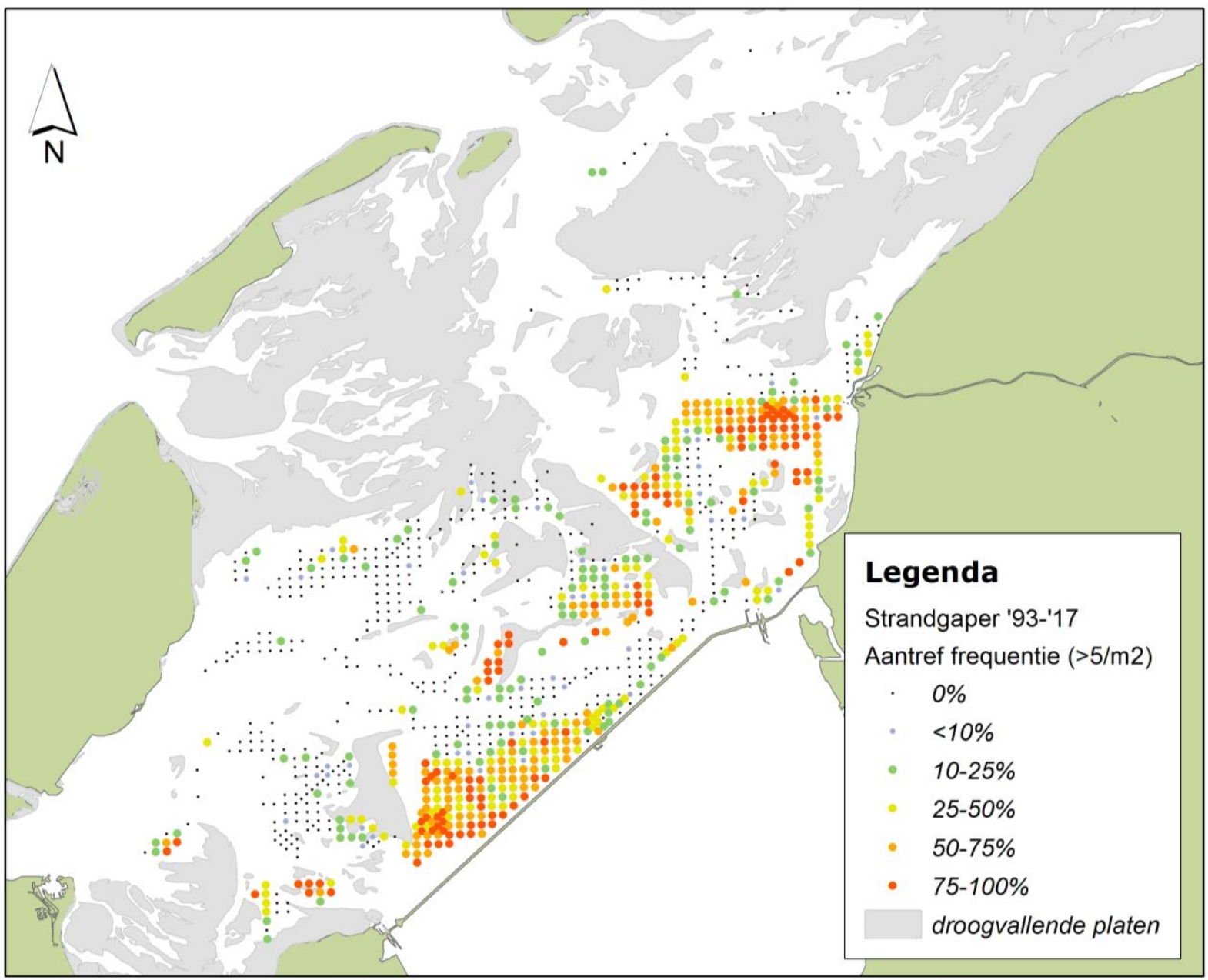

Figuur 14. Verspreiding van strandgapers in het sublitoraal van de westelijke Waddenzee, uitgedrukt als de frequentie van aantreffen van dichtheden groter dan 5 per $\boldsymbol{m}^{2}$ in de periode 1993-2017 (de soort is niet geregistreerd in 1995 en 1996). Monsterpunten die minder dan 4x bemonsterd zijn, zijn niet weergegeven. 


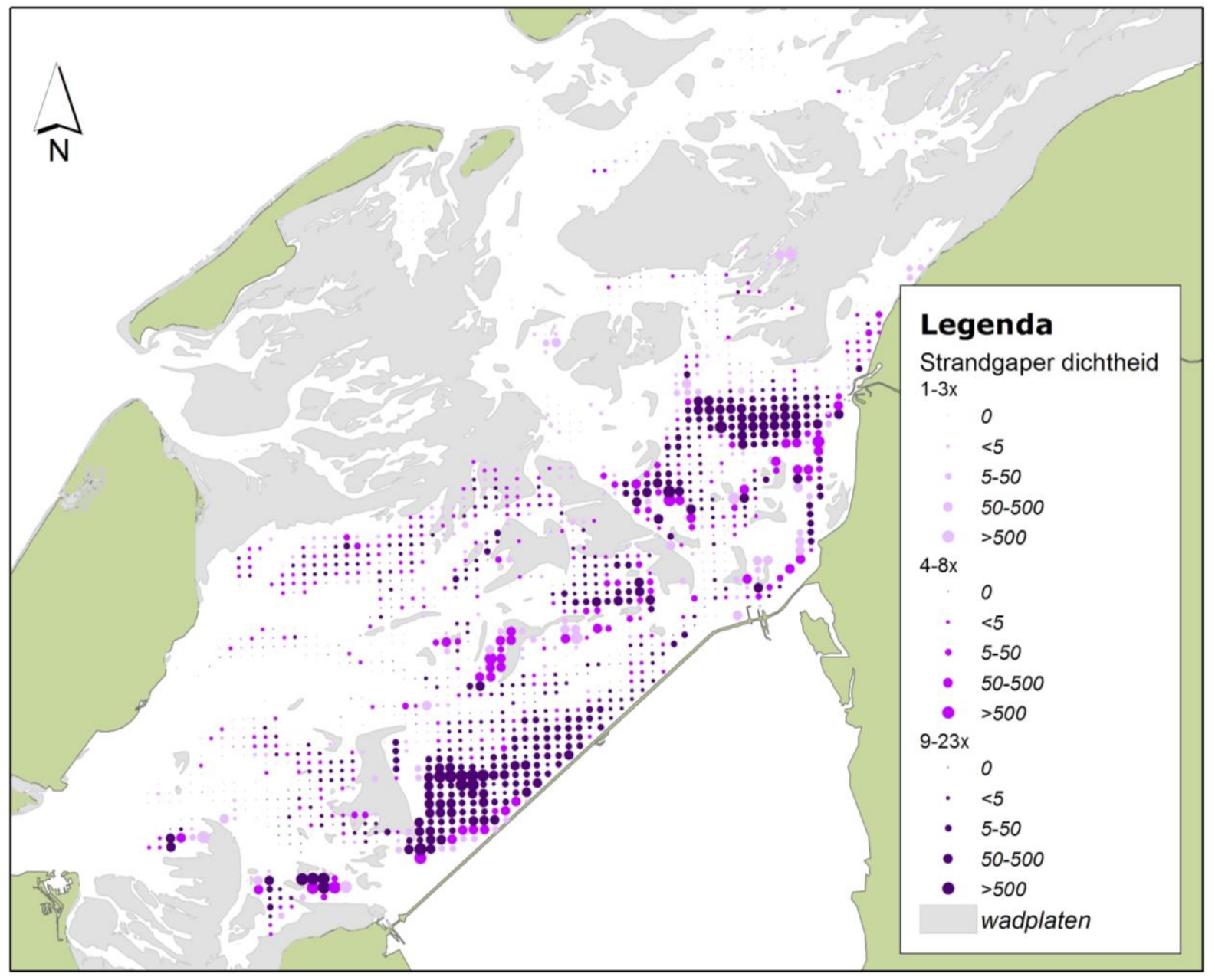

Figuur 15. Gemiddelde dichtheid van strandgapers (aantal per $\mathrm{m}^{2}$ ) in het sublitoraal van de westelijke Waddenzee, berekend over alle jaren waarin een monsterpunt bemonsterd is in de periode 1993-2017, opgedeeld in drie categorieën van bemonsteringsfrequentie (1-3x, 4-8x en 9-23x bemonsterd; de soort is niet geregistreerd in 1995 en 1996).

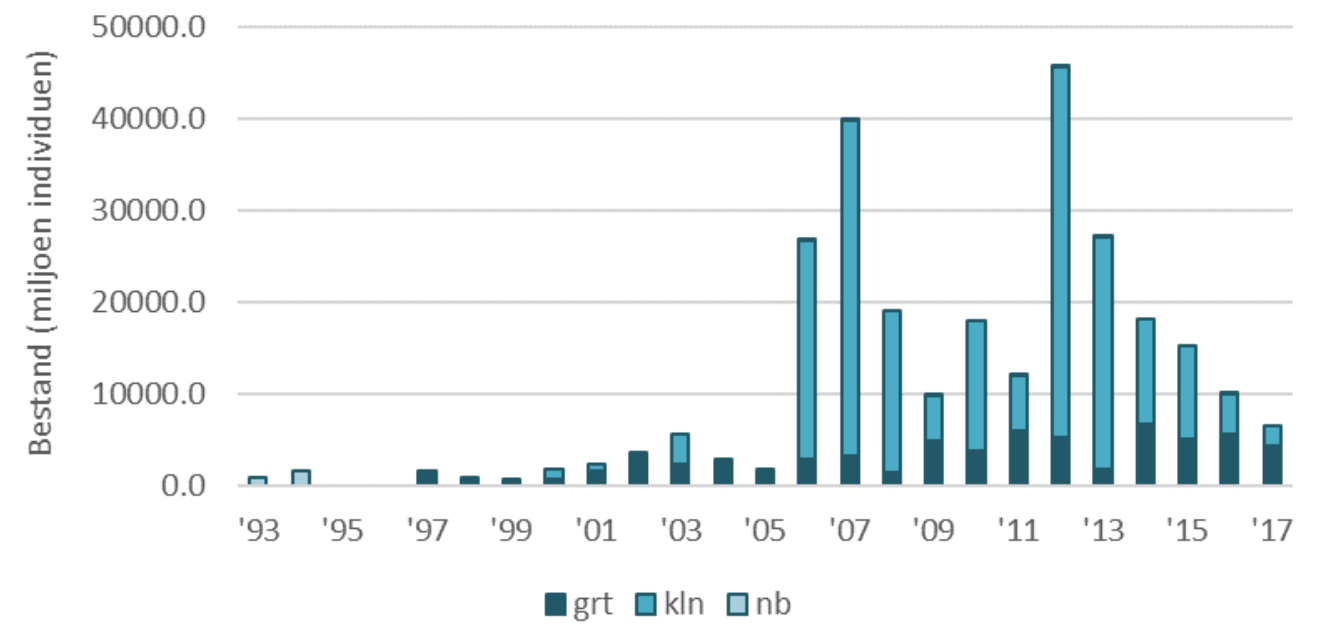

Figuur 16: Het bestand aan strandgapers (in miljoen individuen) in de periode 1993 - 2017. In de jaren 1995 en 1996 is de soort niet geregistreerd. Vanaf 1997 is onderscheid is gemaakt tussen grote en kleine strandgapers. 


\subsection{Amerikaanse zwaardschede (Ensis leei)}

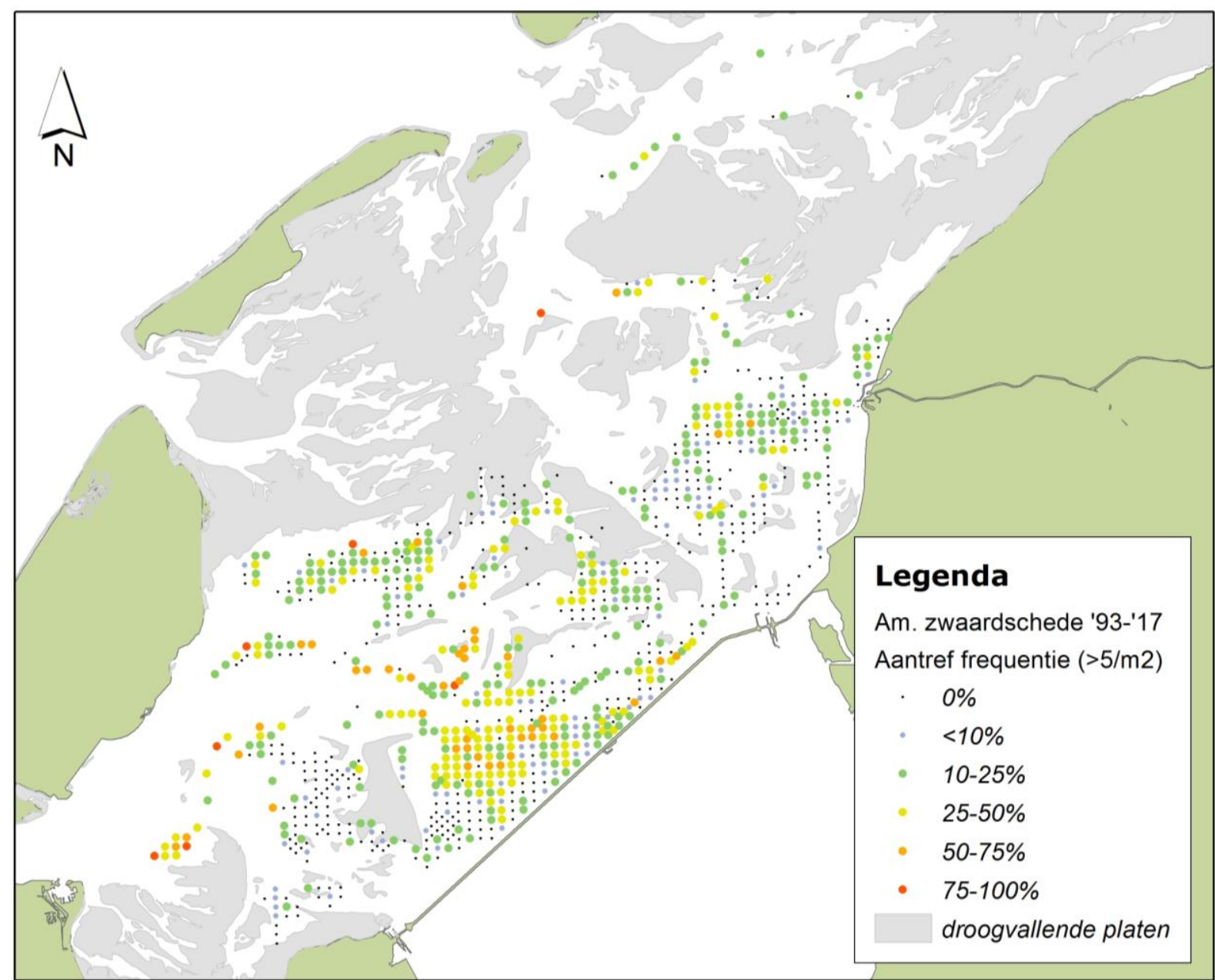

Figuur 17. Verspreiding van Amerikaanse zwaardscheden in het sublitoraal van de westelijke Waddenzee, uitgedrukt als de frequentie van aantreffen van dichtheden groter dan 5 per $\mathbf{m}^{\mathbf{2}}$ in de periode 1993-2017 (de soort is niet geregistreerd in 1995 en 1996). Monsterpunten die minder dan $4 x$ bemonsterd zijn, zijn niet weergegeven. 


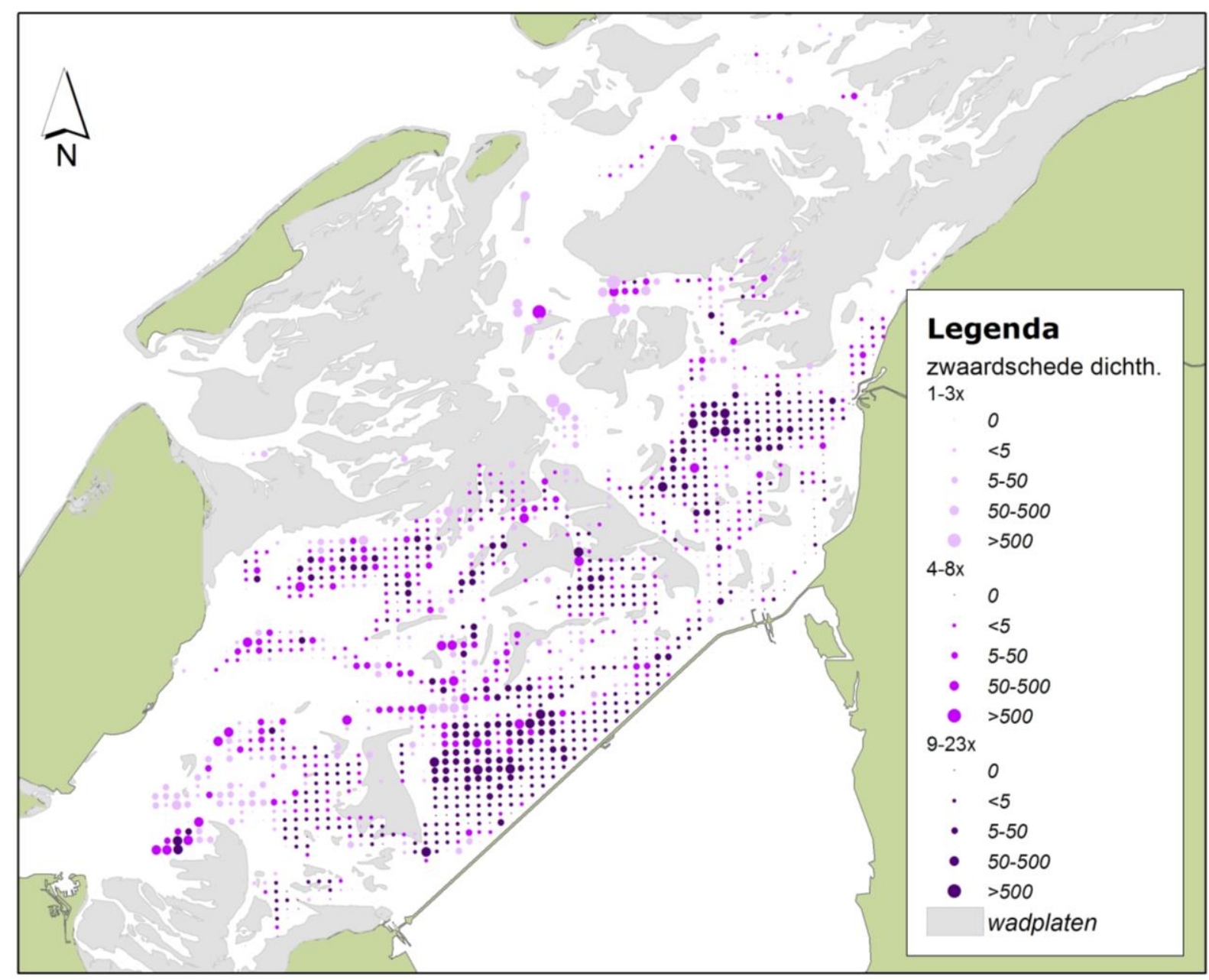

Figuur 18. Gemiddelde dichtheid van Amerikaanse zwaardscheden (aantal per $m^{2}$ ) in het sublitoraal van de westelijke Waddenzee, berekend over alle jaren waarin een monsterpunt bemonsterd is in de periode 1993-2017, opgedeeld in drie categorieën van bemonsteringsfrequentie (1-3x, 4-8x en 9-23x bemonsterd; de soort is niet geregistreerd in 1995 en 1996).

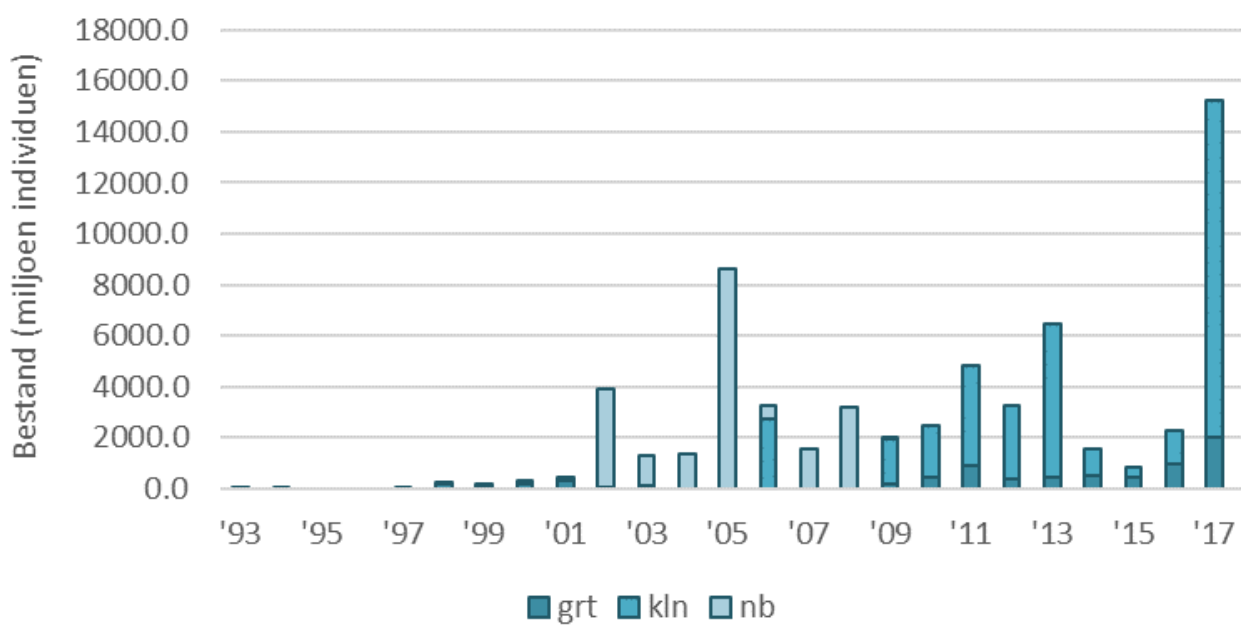

Figuur 19: Het bestand aan Amerikaanse zwaardscheden (in miljoen individuen; niet gecorrigeerd voor vangst-efficiëntie (64\%), zie tekst) in de periode 1993 - 2017. In 1995 en 1996 is de soort niet geregistreerd. 


\subsection{Nonnetje (Limecola balthica)}

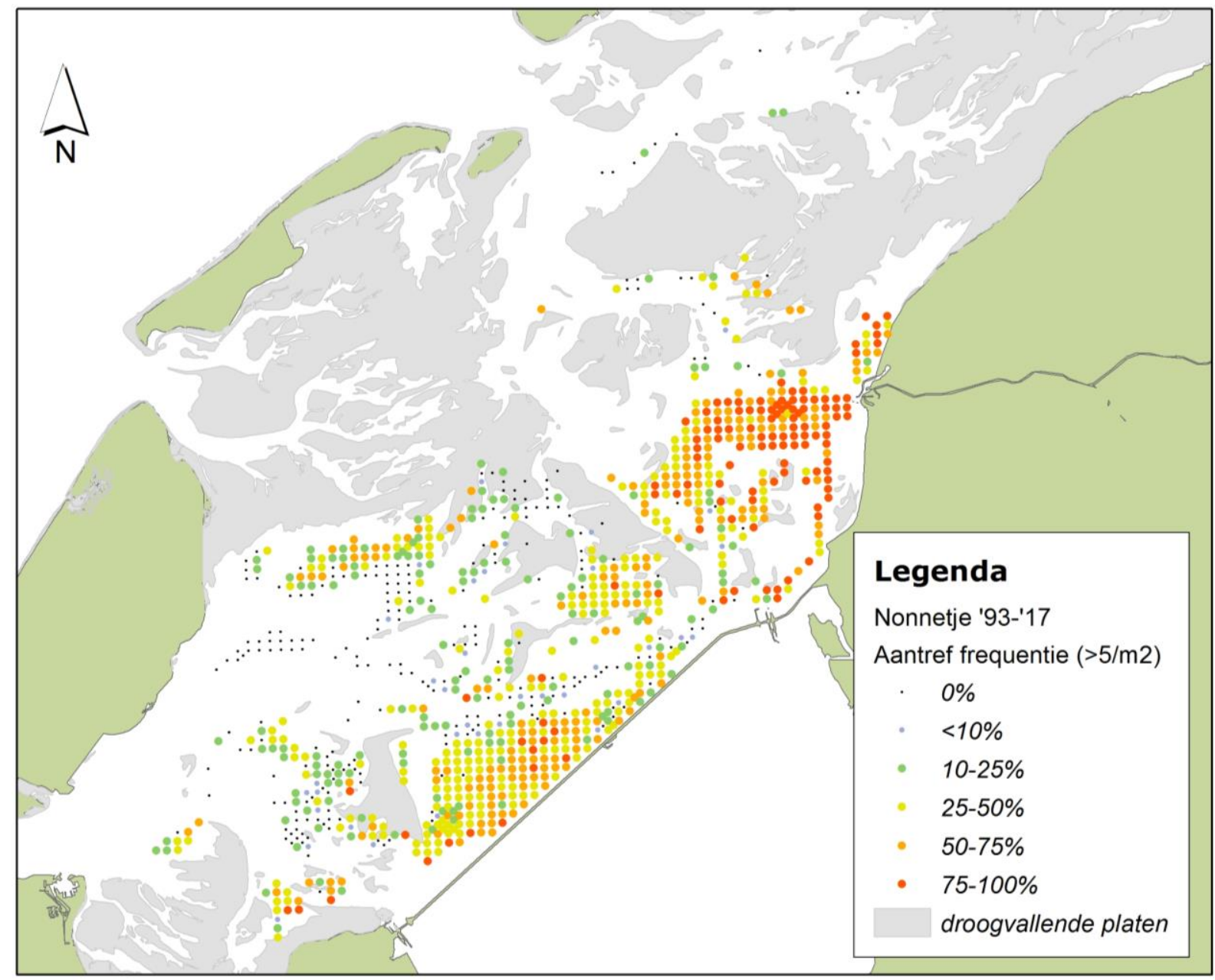

Figuur 20. Verspreiding van nonnetjes in het sublitoraal van de westelijke Waddenzee, uitgedrukt als de frequentie van aantreffen van dichtheden groter dan 5 per $\mathbf{m}^{2}$ in de periode 1993-2017 (de soort is niet geregistreerd in 1995 en 1996). Monsterpunten die minder dan 4x bemonsterd zijn, zijn niet weergegeven. 


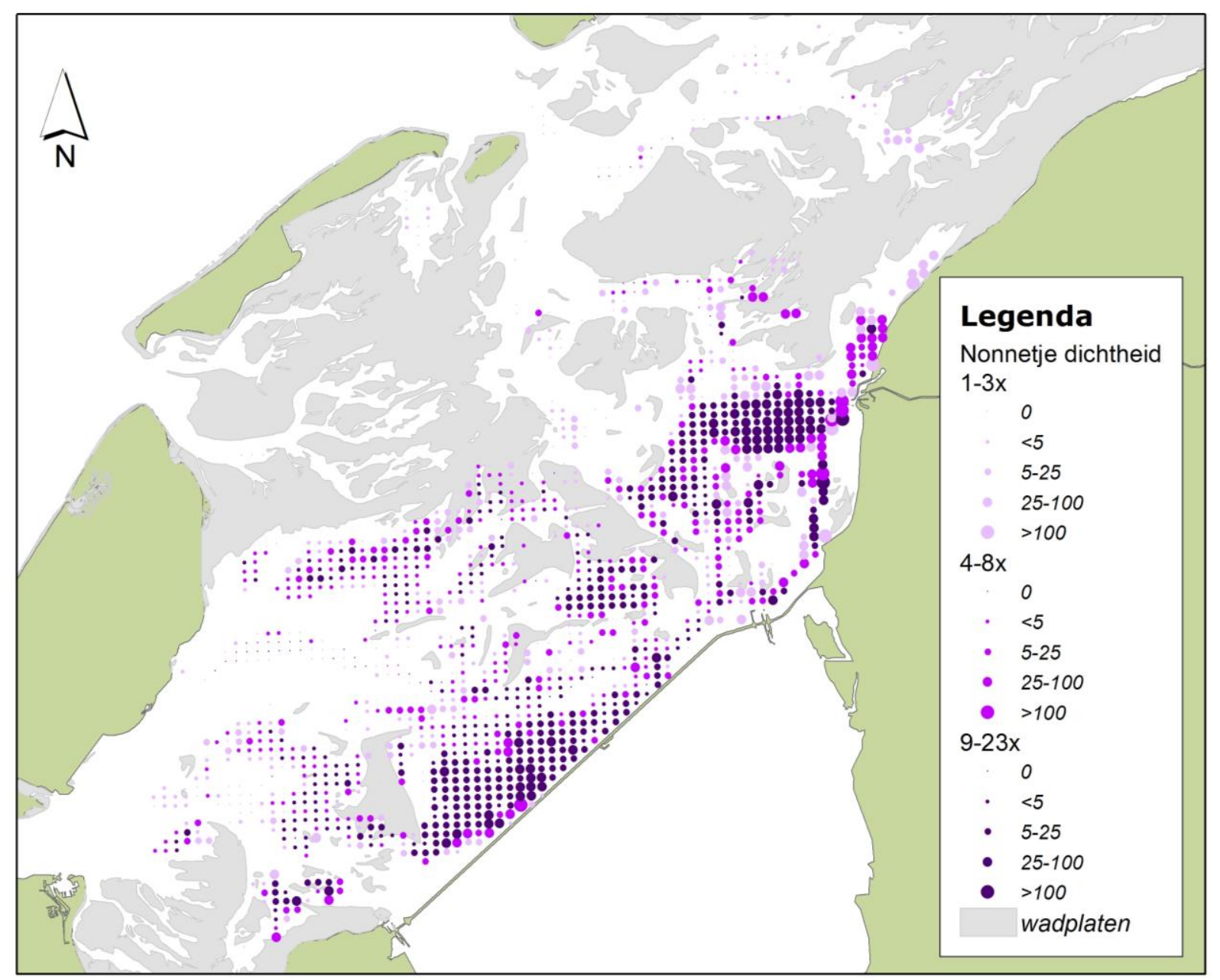

Figuur 21. Gemiddelde dichtheid van nonnetjes (aantal per $\mathrm{m}^{2}$ ) in het sublitoraal van de westelijke Waddenzee, berekend over alle jaren waarin een monsterpunt bemonsterd is in de periode 19932017, opgedeeld in drie categorieën van bemonsteringsfrequentie (1-3x, 4-8x en 9-23x bemonsterd; de soort is niet geregistreerd in 1995 en 1996). 


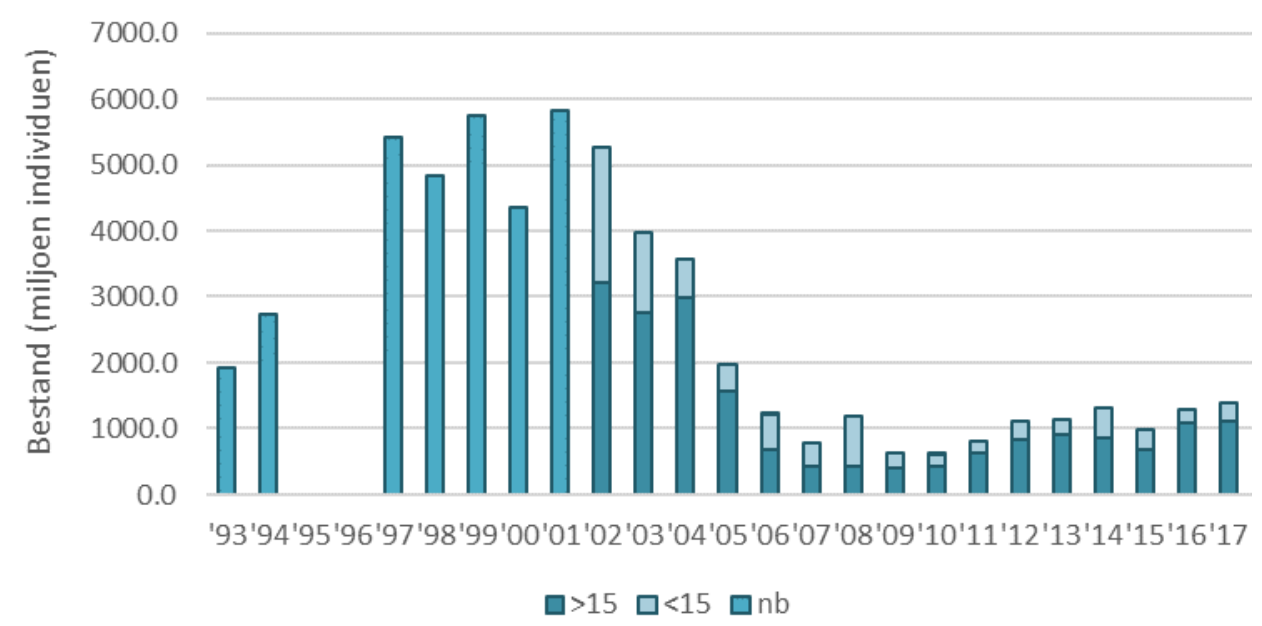

Figuur 22: Het bestand aan nonnetjes (in miljoen individuen) in de periode 1993 - 2017. In de jaren 1995 en 1996 is de soort niet geregistreerd. Vanaf 2002 is onderscheid gemaakt tussen nonnetjes $>15 \mathrm{~mm}$ en $<15 \mathrm{~mm}$.

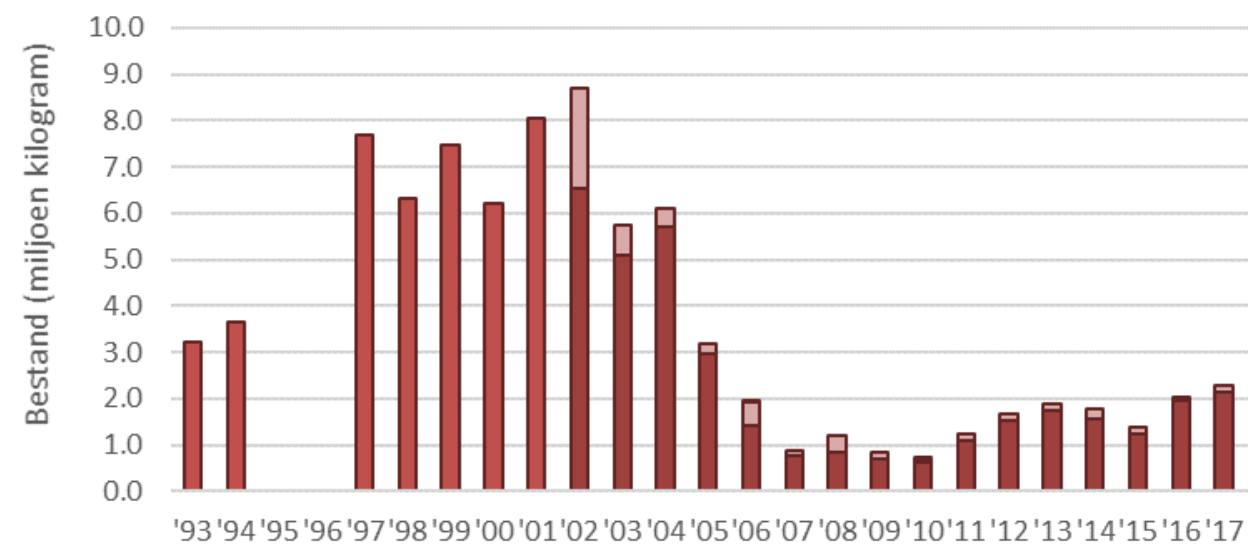

घ>15 $\square<15$ anb

Figuur 23: Het bestand aan nonnetjes (in miljoen kilo natgewicht) in de periode 1993 - 2017. In de jaren 1995 en 1996 is de soort niet geregistreerd. Vanaf 2002 is onderscheid gemaakt tussen nonnetjes $>15 \mathrm{~mm}$ en $<15 \mathrm{~mm}$. 


\subsection{Japanse oester (Crassostrea gigas)}

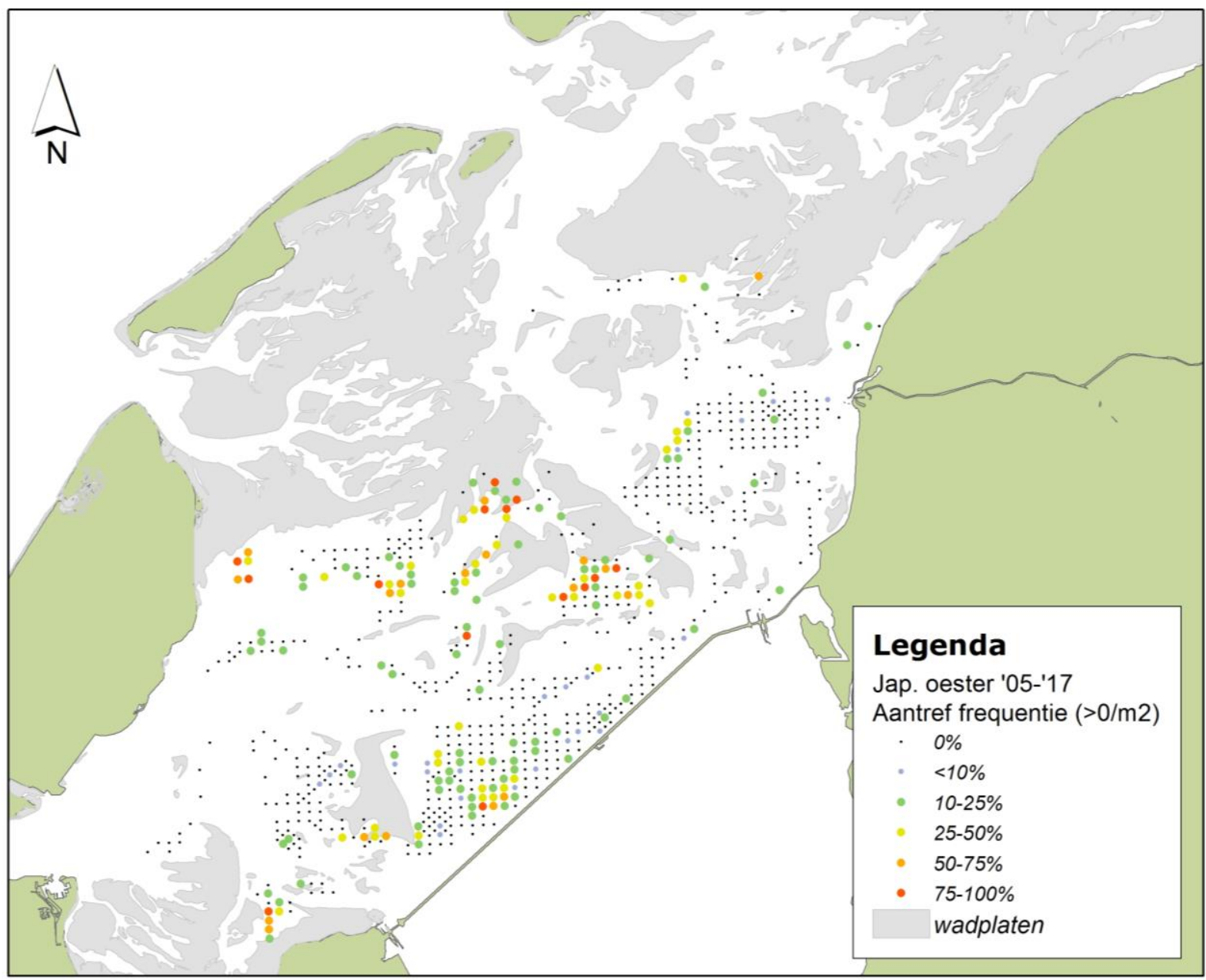

Figuur 24. Verspreiding van Japanse oesters in het sublitoraal van de westelijke Waddenzee, uitgedrukt als de frequentie van aantreffen (dichtheden groter dan 0 per $\mathrm{m}^{2}$ ) in de periode 20052017. Monsterpunten die minder dan $4 x$ bemonsterd zijn, zijn niet weergegeven. 


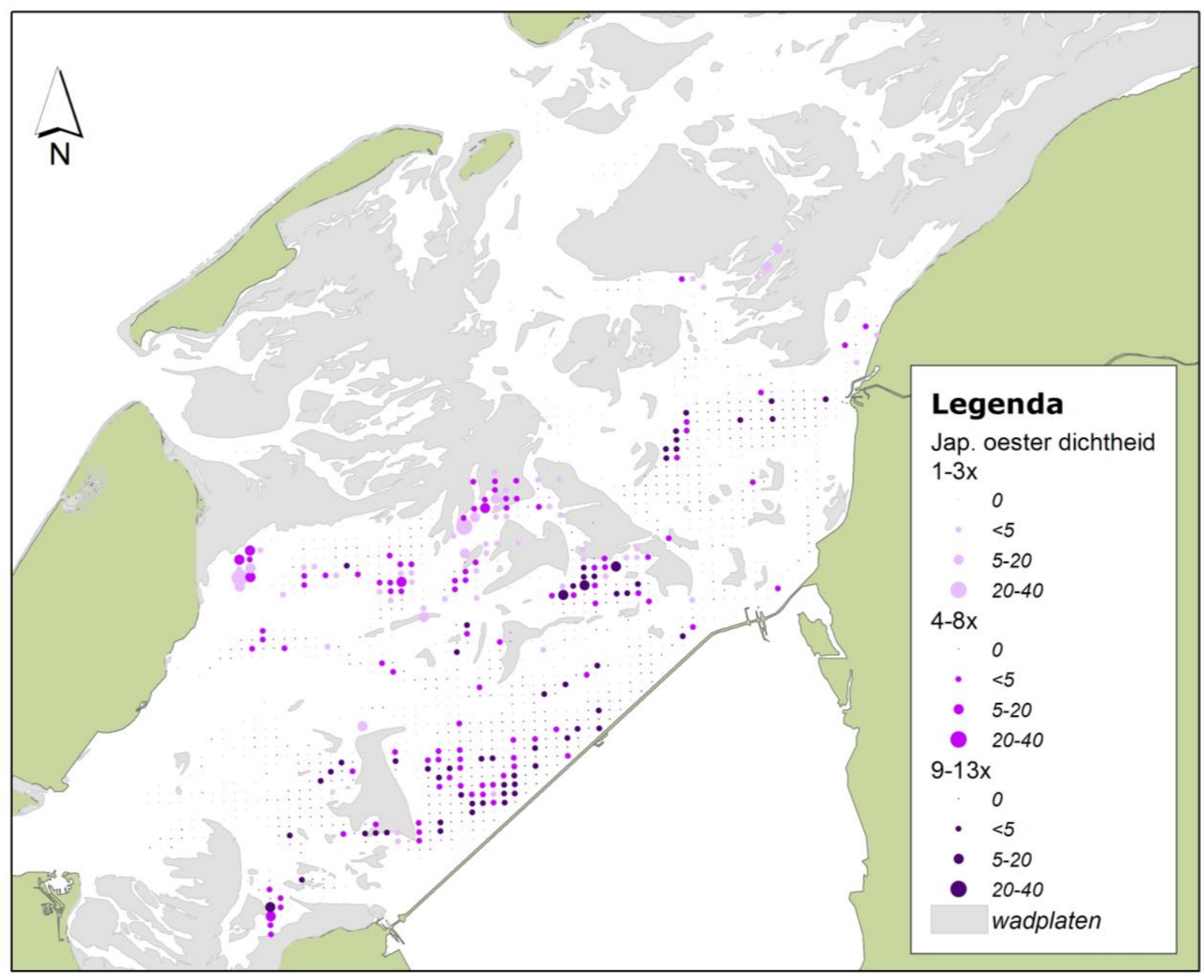

Figuur 25. Gemiddelde dichtheid van Japanse oesters (aantal per $m^{2}$ ) in het sublitoraal van de westelijke Waddenzee, berekend over alle jaren waarin een monsterpunt bemonsterd is in de periode 1993-2017, opgedeeld in drie categorieën van bemonsteringsfrequentie (1-3x, 4-8x en 9-23x bemonsterd; de soort is niet geregistreerd in 1995 en 1996). 


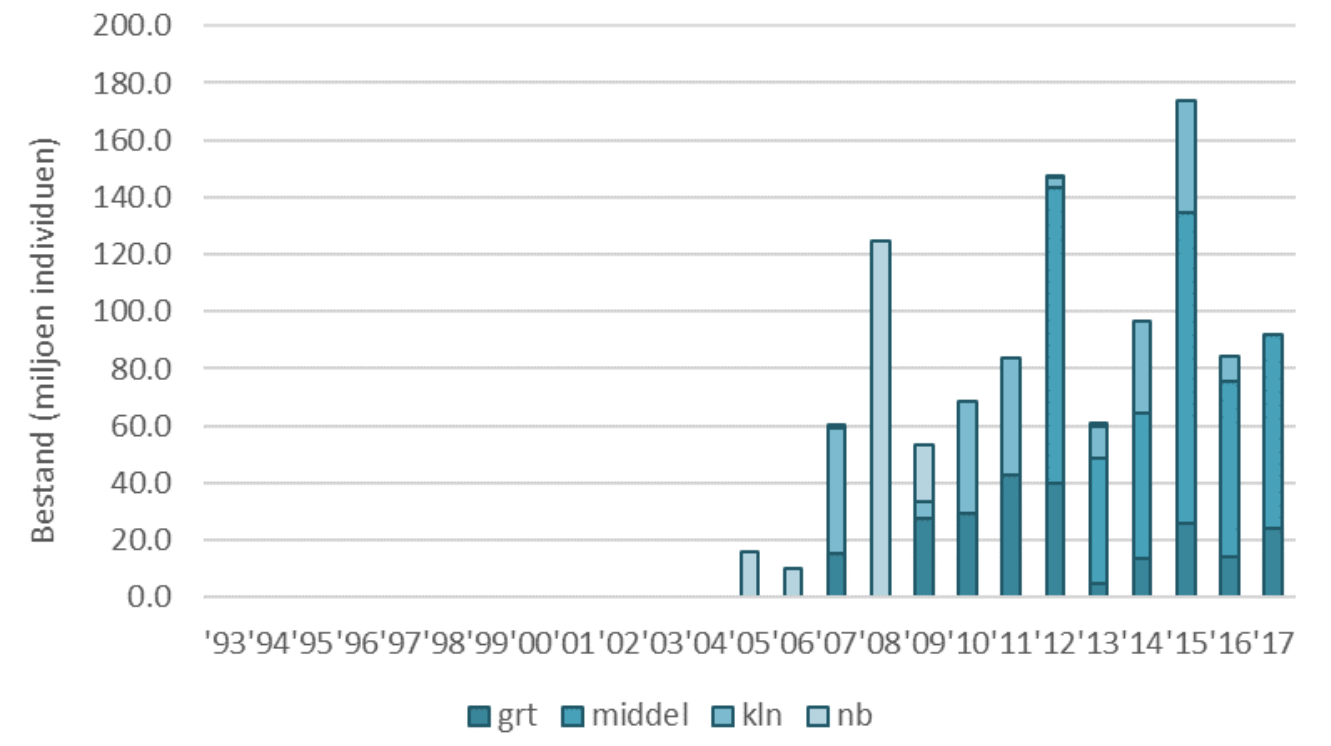

Figuur 26: Het bestand aan Japanse oesters (in miljoen individuen) in de periode 1993 - 2017. De soort wordt sinds 2005 aangetroffen. Sinds 2010 wordt consequent onderscheid gemaakt tussen klein $(1-5 \mathrm{~cm})$, middel $(5-15 \mathrm{~cm})$ en groot $(>15 \mathrm{~cm})$. Broed kleiner dan $1 \mathrm{~cm}$ wordt niet geregistreerd.

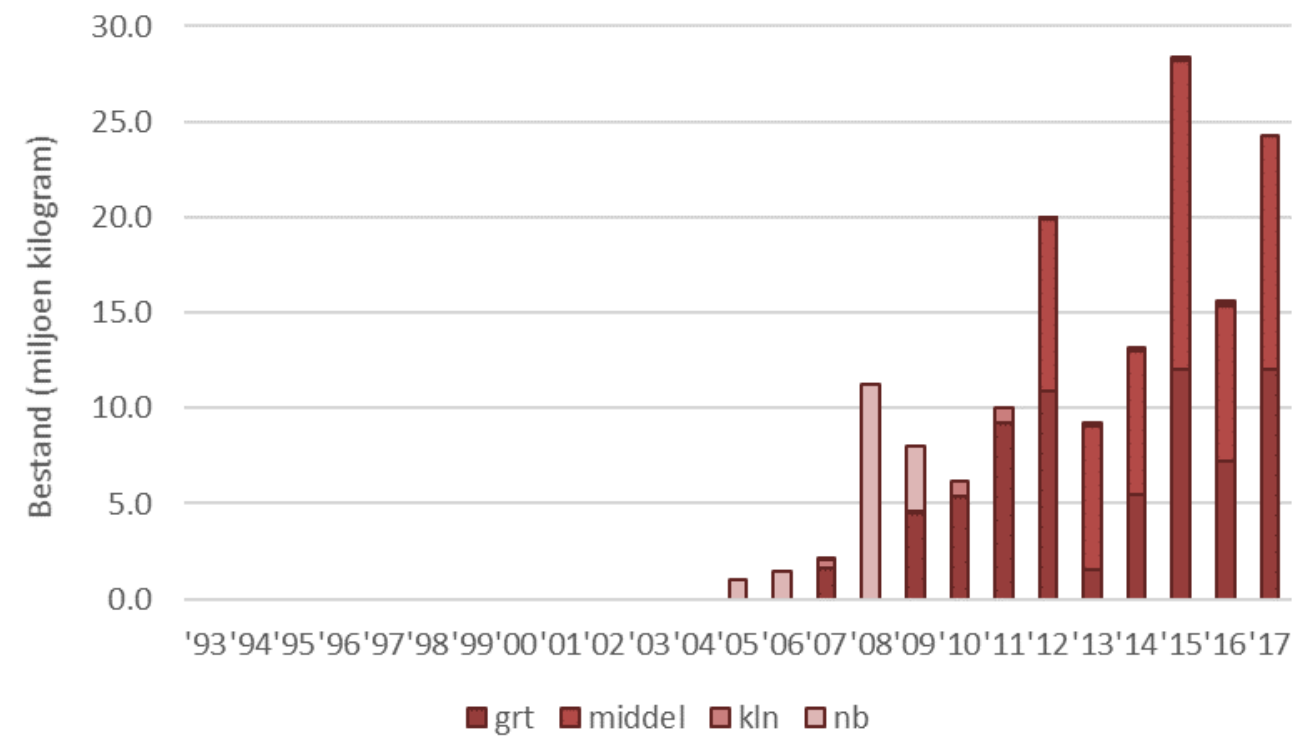

Figuur 27: Het bestand aan Japanse oesters (in miljoen kilogram natgewicht incl. schelp) in de periode 1993 - 2017. De soort wordt sinds 2005 aangetroffen. Sinds 2010 wordt consequent onderscheid gemaakt tussen klein $(1-5 \mathrm{~cm})$, middel $(5-15 \mathrm{~cm})$ en groot $(>15 \mathrm{~cm})$. Broed kleiner dan $1 \mathrm{~cm}$ wordt niet geregistreerd. 


\subsection{Muiltje (Crepidula fornicata)}

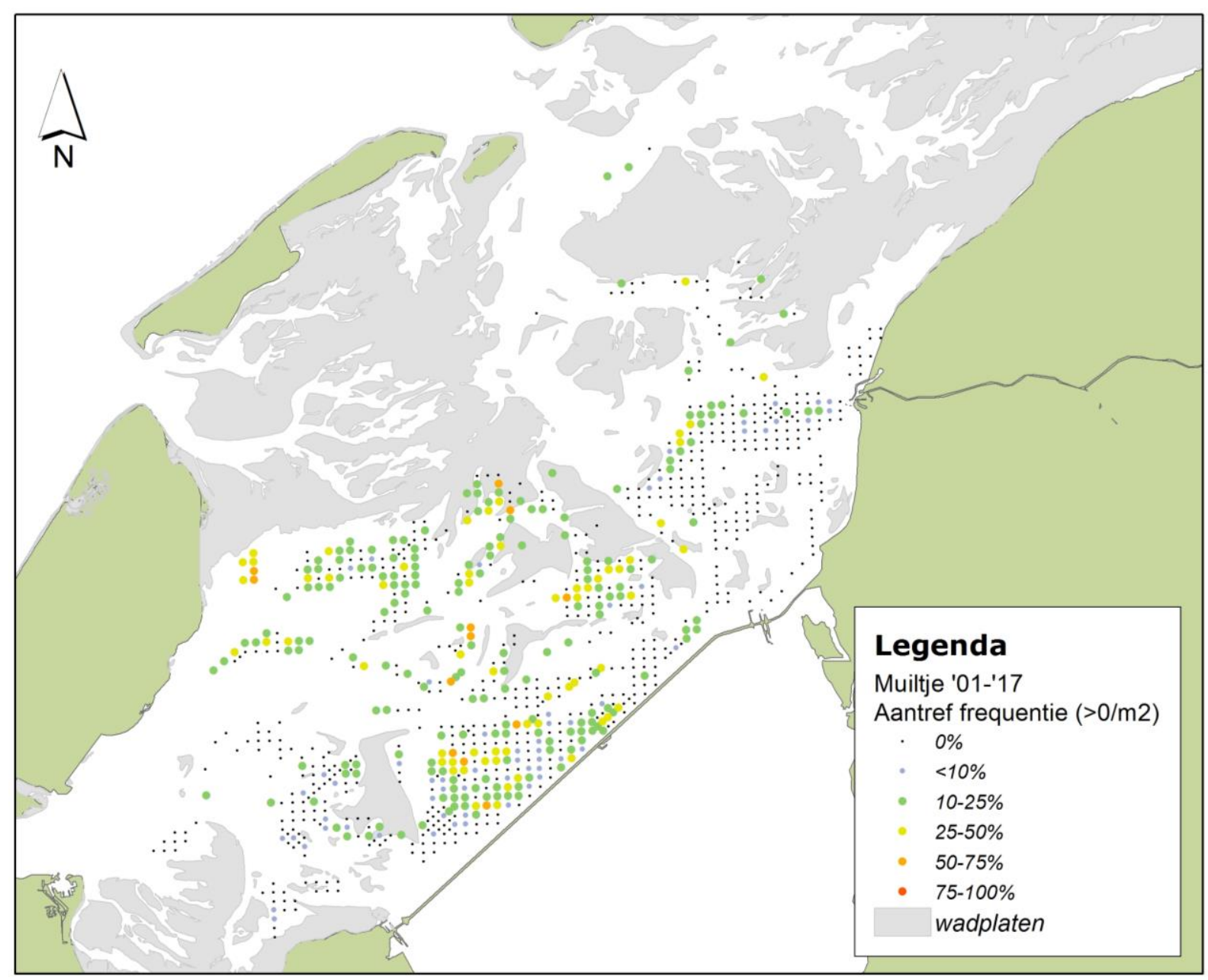

Figuur 28. Verspreiding van muiltjes in het sublitoraal van de westelijke Waddenzee, uitgedrukt als de frequentie van aantreffen (dichtheden groter dan 0 per $\mathrm{m}^{2}$ ) in de periode 2001-2017. Monsterpunten die minder dan $4 x$ bemonsterd zijn, zijn niet weergegeven. 


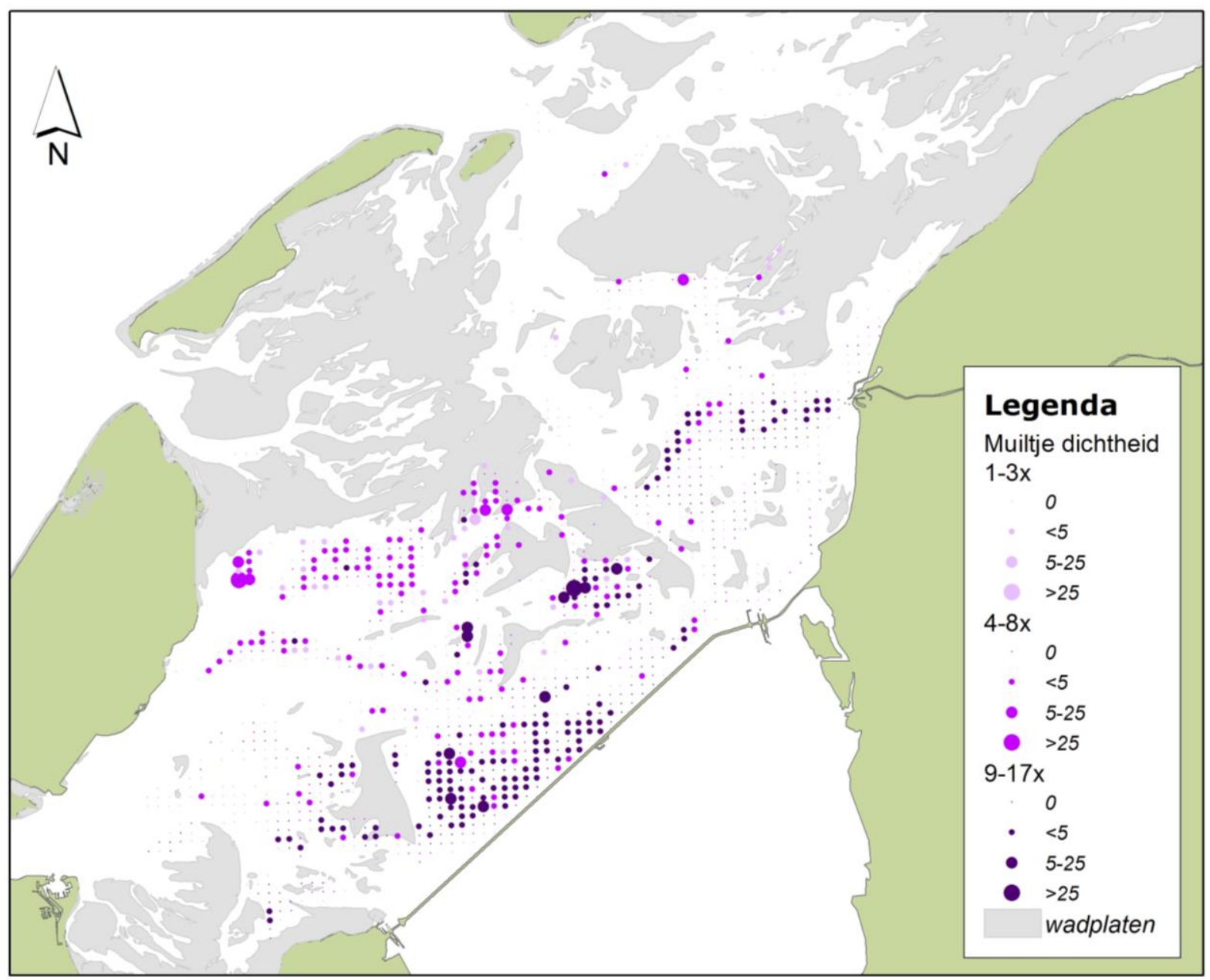

Figuur 29. Gemiddelde dichtheid van muiltjes (aantal per $\mathrm{m}^{2}$ ) in het sublitoraal van de westelijke Waddenzee, berekend over alle jaren waarin een monsterpunt bemonsterd is in de periode 20012017, opgedeeld in drie categorieën van bemonsteringsfrequentie (1-3x, 4-8x en 9-17x bemonsterd). 


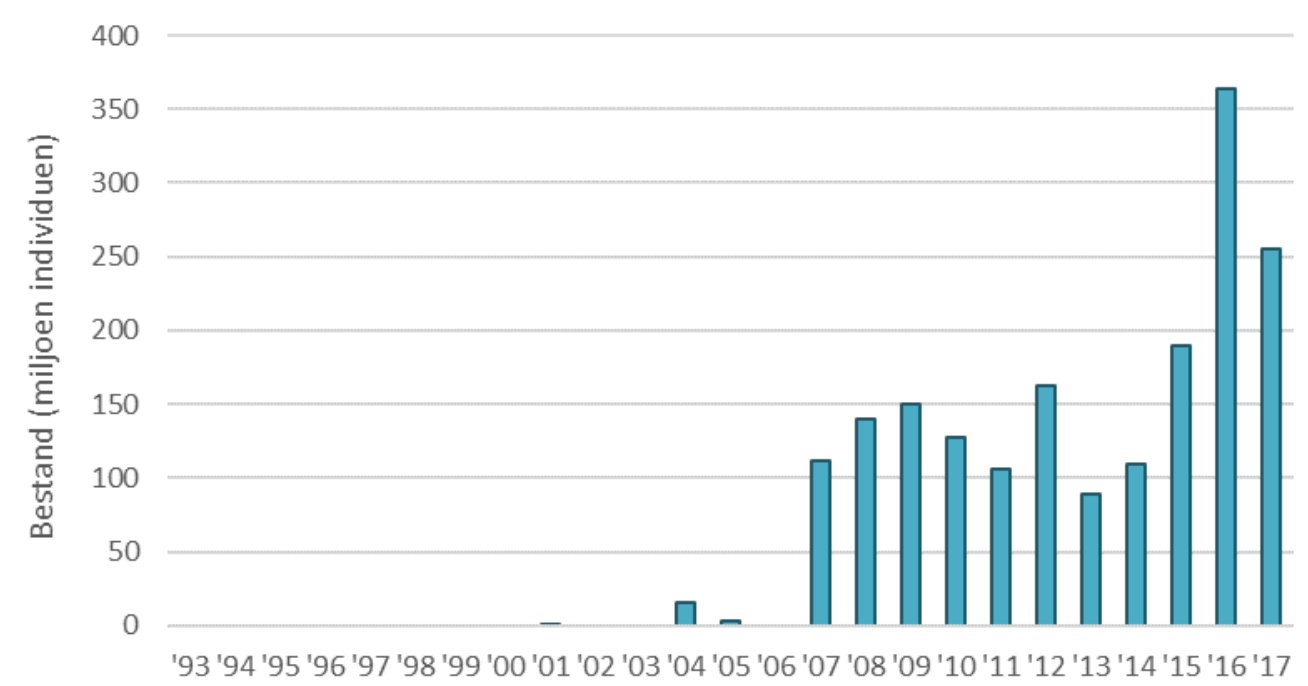

Figuur 30: Het bestand aan muiltjes (in miljoen individuen incl. schelp) in de periode $1993-2017$. De soort is in 2001 voor het eerst aangetroffen.

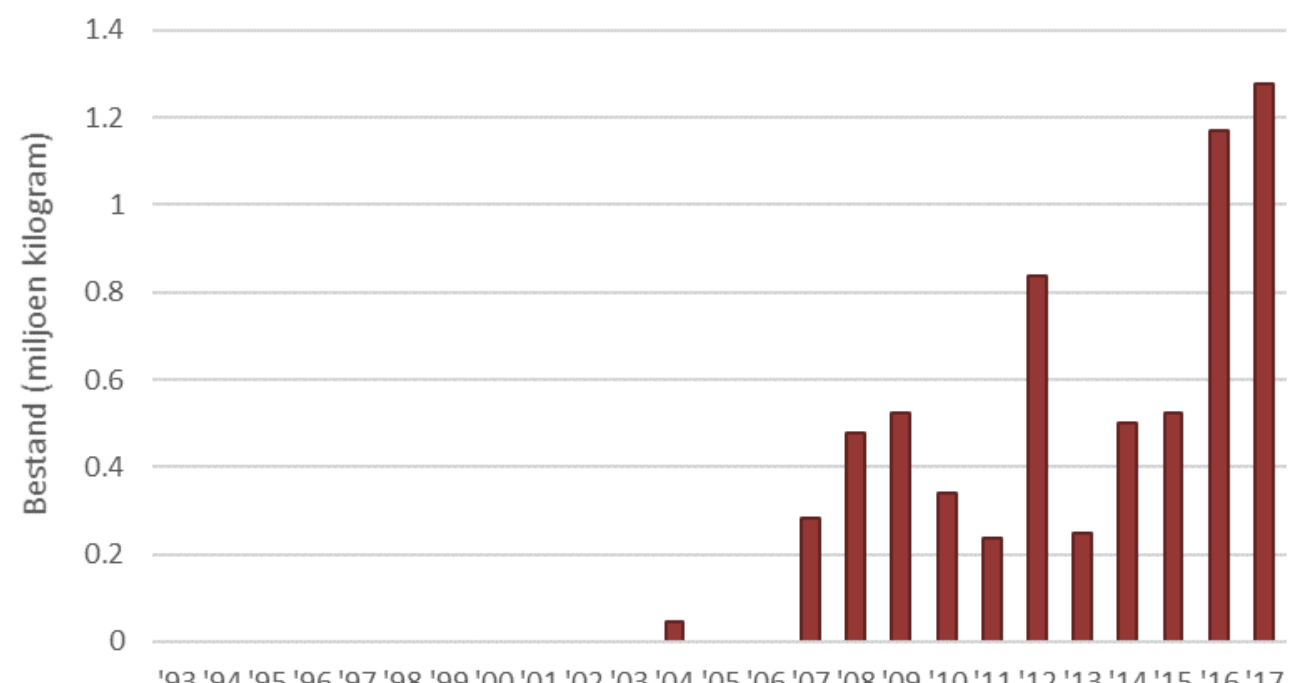

Figuur 31: Het bestand aan muiltjes (in miljoen kilo natgewicht incl. schelp) in de periode 1993 2017. De soort is in 2001 voor het eerst aangetroffen. 


\subsection{Strandkrab (Carcinus maenas)}

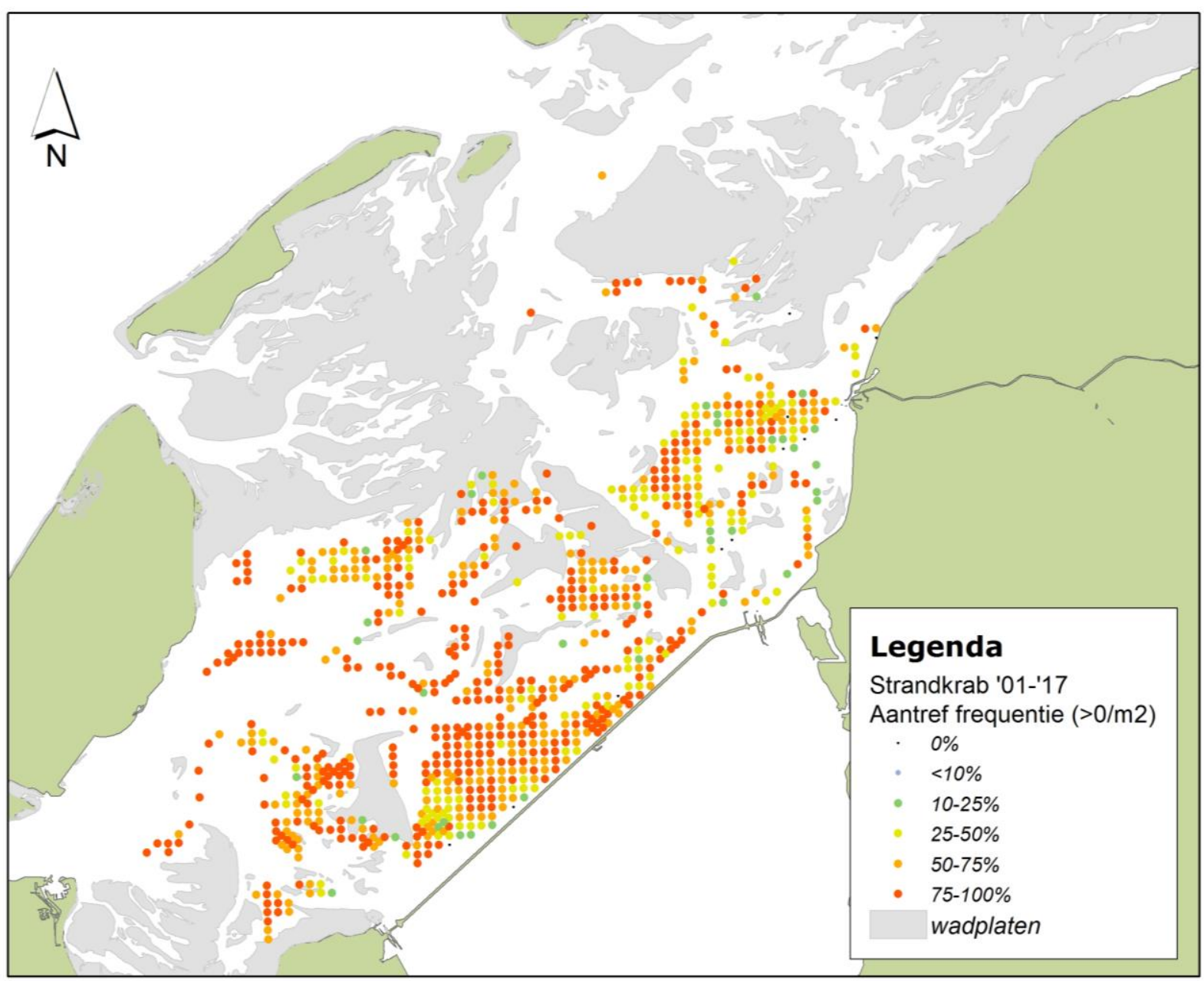

Figuur 32. Verspreiding van strandkrabben in het sublitoraal van de westelijke Waddenzee, uitgedrukt als de frequentie van aantreffen (dichtheden groter dan 0 per $\mathrm{m}^{2}$ ) in de periode 20012017. Monsterpunten die minder dan $4 x$ bemonsterd zijn, zijn niet weergegeven. 


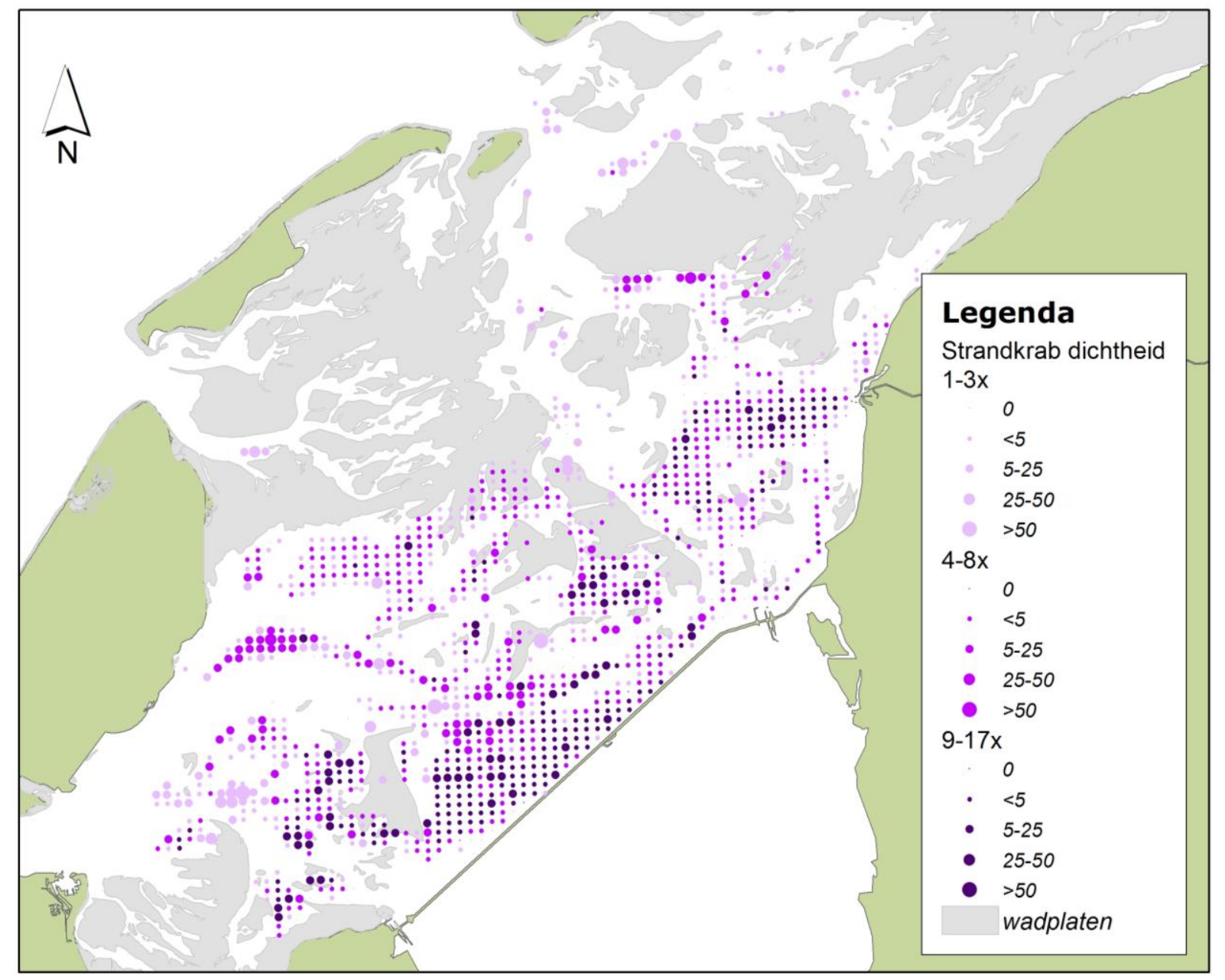

Figuur 33. Gemiddelde dichtheid van strandkrabben (aantal per $\mathrm{m}^{2}$ ) in het sublitoraal van de westelijke Waddenzee, berekend over alle jaren waarin een monsterpunt bemonsterd is in de periode 2001-2017, opgedeeld in drie categorieën van bemonsteringsfrequentie (1-3x, 4-8x en 9-17x bemonsterd). 


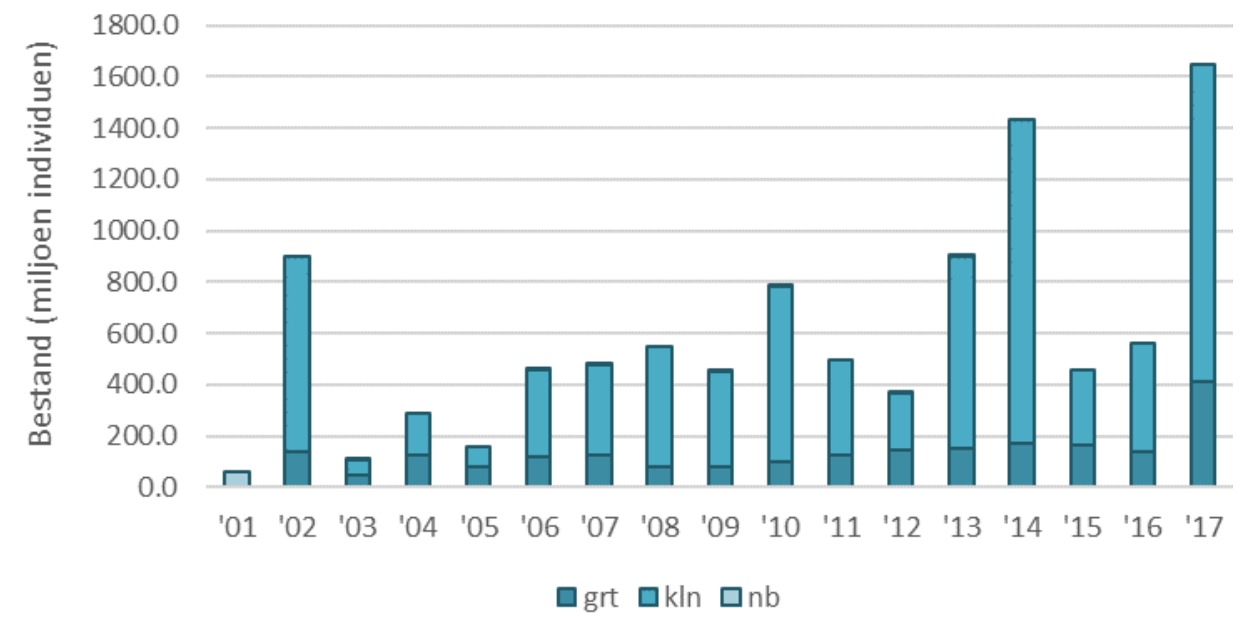

Figuur 34. Het bestand aan strandkrabben (in miljoen individuen) in de periode 2001 - 2017. Vanaf 2002 is onderscheid gemaakt tussen grote (carapax $<2,5 \mathrm{~cm}$ ) en kleine (carapax $>2,5 \mathrm{~cm}$ ) individuen.

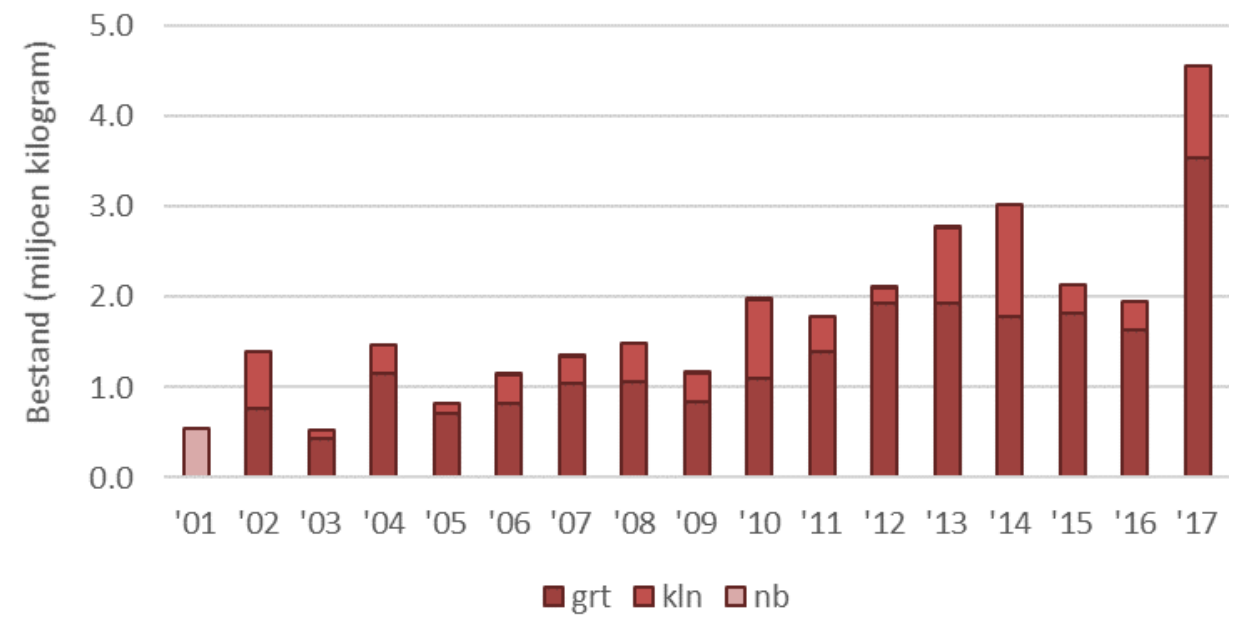

Figuur 35. Het bestand aan strandkrabben (in miljoen kilo natgewicht) in de periode 2001 2017. Vanaf 2002 is onderscheid gemaakt tussen grote (carapax $<2,5 \mathrm{~cm}$ ) en kleine (carapax $>2,5$ $\mathrm{cm}$ ) individuen. 


\subsection{Penseel of blaasjeskrab (Hemigrapsus sp.)}

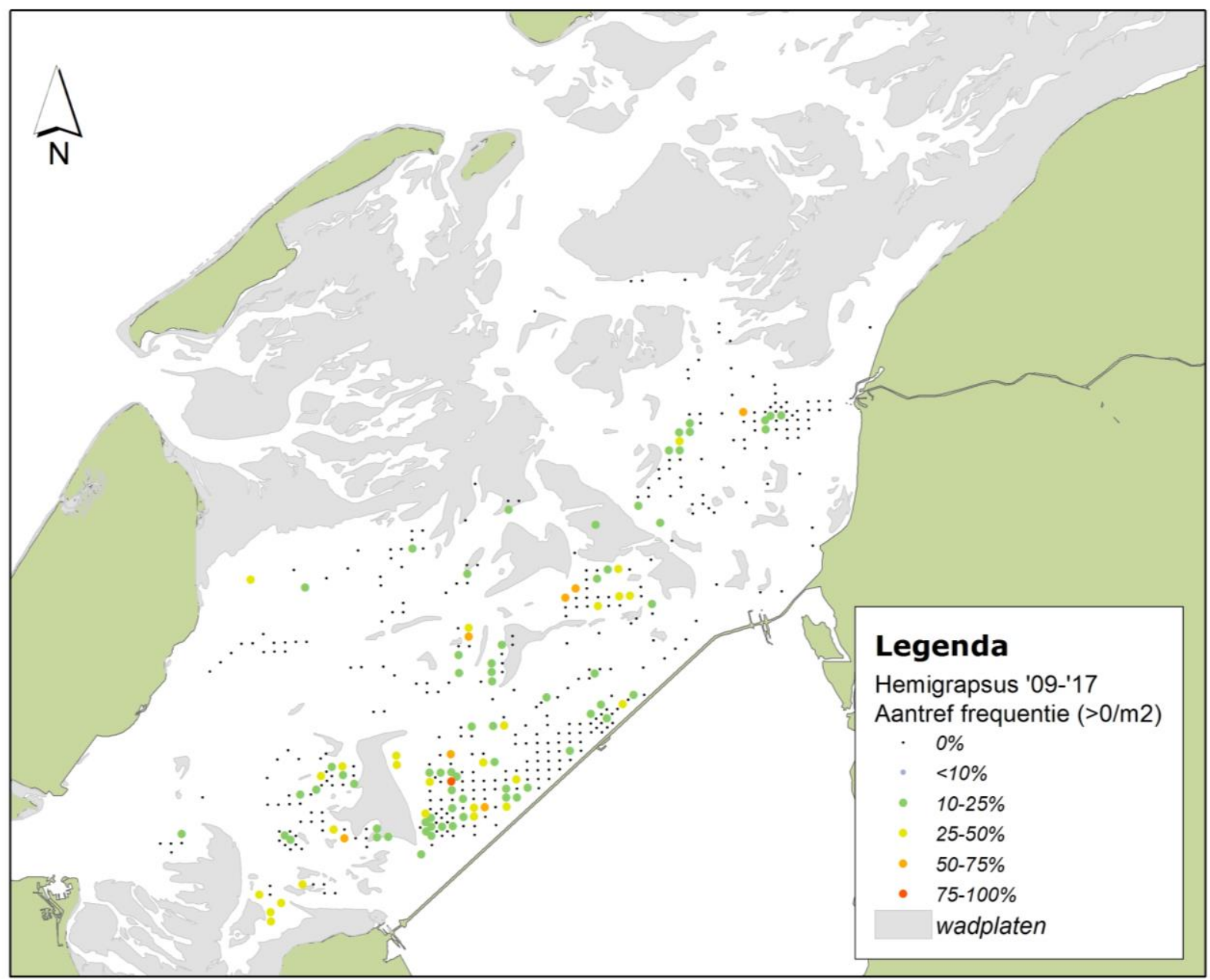

Figuur 36. Verspreiding van penseel- en blaasjeskrabben (genus Hemigrapsus) in het sublitoraal van de westelijke Waddenzee, uitgedrukt als de frequentie van aantreffen van dichtheden groter dan 5 per $\mathbf{m}^{2}$ in de periode 2009-2017. Monsterpunten die minder dan 4x bemonsterd zijn, zijn niet weergegeven. 


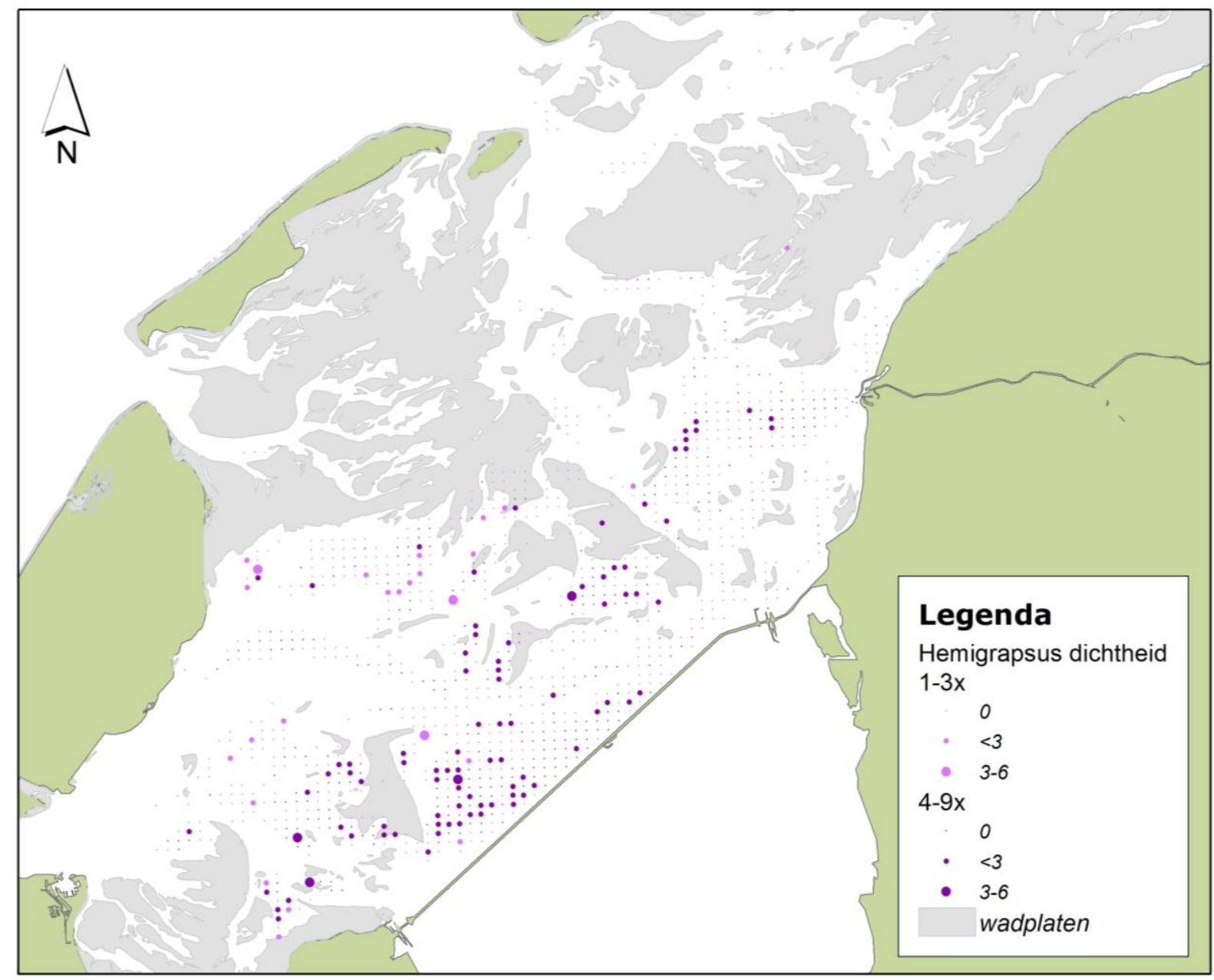

Figuur 37. Gemiddelde dichtheid van penseel- en blaasjeskrabben (genus Hemigrapsus; aantal per $\mathrm{m}^{2}$ ) in het sublitoraal van de westelijke Waddenzee, berekend over alle jaren waarin een monsterpunt bemonsterd is in de periode 2009-2017, opgedeeld in twee categorieën van bemonsteringsfrequentie (1-3x en 4-9x bemonsterd). 
60

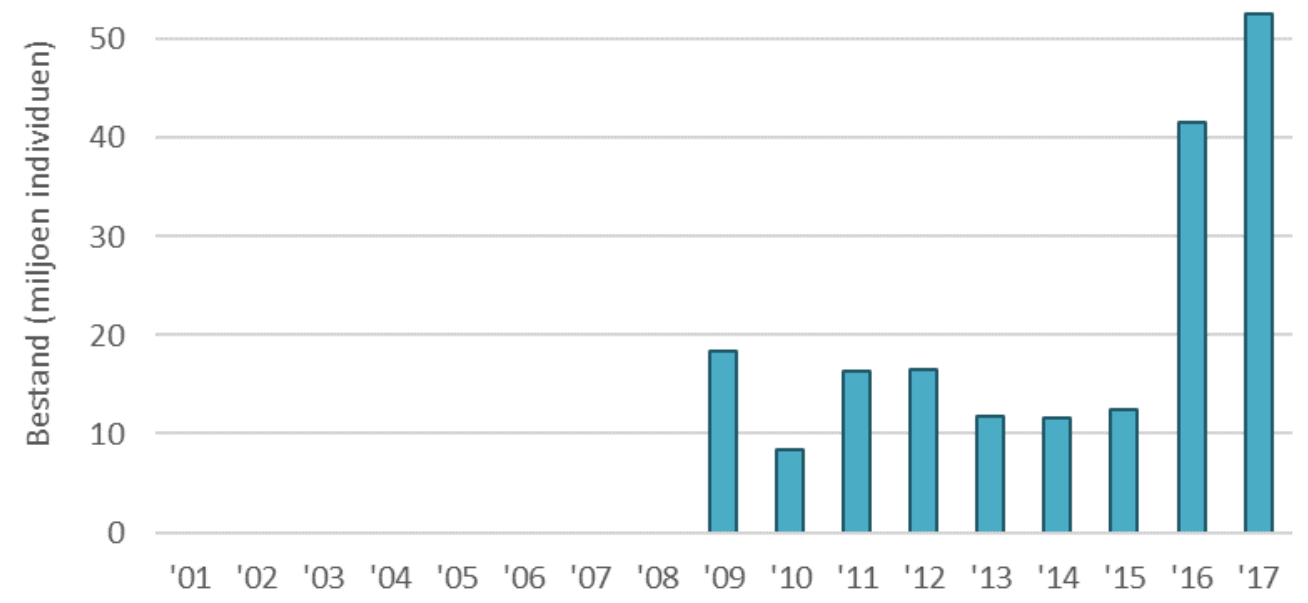

Figuur 38: Het bestand aan penseel- en blaasjeskrabben (in miljoen individuen) in de periode 2001 - 2017. De soort is in 2009 voor het eerst aangetroffen.

0.10

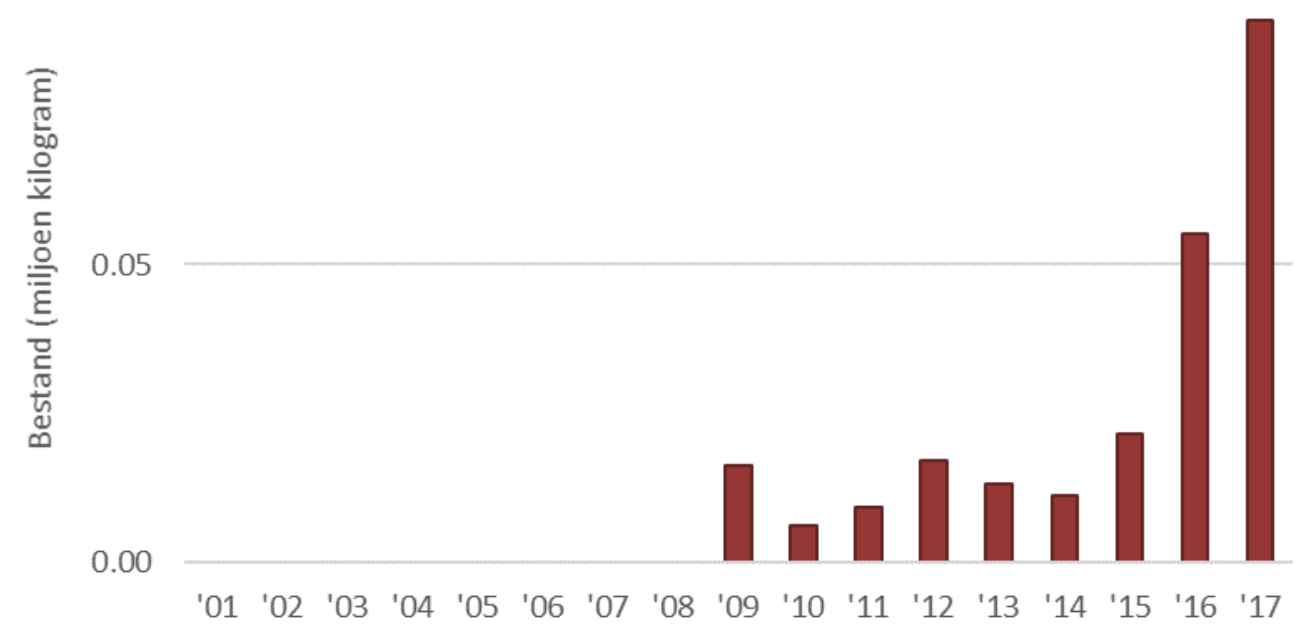

Figuur 39: Het bestand aan penseel- en blaasjeskrabben (Hemigrapsus sp.) (in miljoen kilo natgewicht) in de periode 2001 - 2017. De soort is in 2009 voor het eerst aangetroffen. 


\section{Discussie en conclusies}

\subsection{Ruimtelijke dekking}

Een belangrijke kanttekening bij de gepresenteerde resultaten is de surveys niet de gehele kombergingen Marsdiep en Vliestroom beslaan, maar die delen die potentieel geschikt zijn voor het voorkomen van mosselen / mosselbanken zoals weergegeven in Figuur 1. Dit zijn de gebieden waar tijdens de diverse surveys ooit mosselen zijn aangetroffen of waar op basis van signalen vanuit bijvoorbeeld de garnalenvisserij of Wadden Unit mosselen verwacht werden. Aangezien gebieden waar nooit mosselen voorkomen vaak ook minder of ongeschikt zijn voor veel andere soorten bodemdieren, bijvoorbeeld omdat het er te hard stroomt, geven de gegevens ook voor soorten als kokkels, strandgapers en oesters een goed beeld van hun ruimtelijke verspreiding en langjarige ontwikkeling daarvan.

Van de Amerikaanse zwaardschede is uit eerder onderzoek (binnen het NWO programma Zee- en Kustonderzoek (ZKO), niet gerapporteerd) bekend dat deze wel in substantiële dichtheden buiten het hier gepresenteerde onderzoeksgebied kan voorkomen. Mogelijk geldt dit ook voor soorten als de strandkrab en zeester. Voor deze soorten kunnen de gepresenteerde bestandsgroottes dus onderschat zijn. Om die reden wordt sinds 2015 in opdracht van het ministerie van LNV een aanvullende monitoring uitgevoerd die zich specifiek richt op Amerikaanse zwaardscheden in de gebieden die door de mosselzaadinventarisatie onvolledig gedekt worden. Deze aanvullende bemonstering is niet verwerkt in de in dit rapport weergegeven kaarten en grafieken. Verspreidingskaarten en tijdreeksen inclusief de aanvullende bemonstering worden opgenomen in de WOT rapportage van het bestand aan Amerikaanse zwaardscheden in de westelijke Waddenzee, te verschijnen in 2020.

\subsection{Vangst-efficiëntie}

Het bestand aan Japanse oesters vóór 2012 is mogelijk onderschat vanwege het soms smoren van de zuigkor in zeer dichte oesterbanken waardoor monsternames moesten worden overgedaan. Stations met hoge dichtheden oesters worden sinds 2012 om reden daarvan bemonsterd met een hydraulische bodemhapper (zie Van den Ende et al., 2018).

Van diep gravende soorten zoals de strandgaper en Amerikaanse zwaardschede wordt waarschijnlijk een deel gemist omdat de zuigkor en bodemschaaf tot een diepte van $7 \mathrm{~cm}$ monsteren. Voor zwaardscheden is geschat, op basis van een nog niet gepubliceerde vergelijking tussen de zuigkor en een diep gravende bodemhapper (Troost, in prep.), dat maximaal 36\% van de aanwezige dieren wordt gemist. Dit percentage is verschillend tussen verschillende grootteklassen en waarschijnlijk ook tussen verschillende bodemsamenstellingen, omdat zwaardscheden ondieper in de bodem zitten als ze nog klein zijn en omdat ze mogelijk in sommige sedimenten sneller naar beneden kunnen schieten dan in andere (Winter et al. 2012). In afwachting van het lopende onderzoek hiernaar zijn de in dit rapport gebruikte gegevens hiervoor niet gecorrigeerd. Voor strandgapers wordt verwacht dat de efficiëntie van de zuigkor groter is omdat van deze soort niet beschreven is dat ze zich snel in kunnen graven of dat ze snel hun sifonen in kunnen trekken (Gosling 2003).

\subsection{Conclusies}

De bestandsopname van mosselen en daarbij aangetroffen andere soorten heeft over de periode van 1992 tot en met 2017 (26 jaar) een schat aan informatie opgeleverd over de ontwikkeling van bodemdieren (met name scheldpdieren) in het sublitoraal van de westelijke Waddenzee. Door de gegevens uit te werken, zoals hier gepresenteerd, worden ze toegankelijk gemaakt voor toepassing in 
onderzoek, beleid en beheer in de Waddenzee. Omdat de focus van de survey ligt op mosselen en daardoor niet het sublitoraal van de gehele Waddenzee wordt gedekt wordt een deel van de bestanden van overige soorten gemist. Geconstateerd wordt dat de voorjaarsinventarisatie, in combinatie met de aanvullende bestandsopnamen voor Amerikaanse zwaardscheden binnen het WOT programma van LNV, het voorkomen van schelpdieren in de kombergingen Vliestroom en Marsdiep afdoende dekt.

Voor soorten met een bredere verspreiding, zoals bijvoorbeeld strandkrabben, is dat minder het geval. Om ook voor deze soorten een volledig beeld te krijgen van hun verspreiding en bestandsgroottes zou de survey, met een relatief geringe extra inspanning, uitgebreid kunnen worden naar de gebieden die nu nog niet voldoende gedekt worden. 


\section{Literatuur}

Gosling, E (2003) Bivalve Molluscs; Biology, Ecology and Culture. Fishing News Books, Blackwell Science. ISBN 0-85238-234-0.

Perdon, KJ, K Troost, J van Zwol, M van Asch \& J van der Pool (2018) Schelpdierbestanden in de Nederlandse kustzone in 2018. Wageningen Marine Research, Centrum voor Visserij Onderzoek. CVO rapport 18.010 .

Troost, K, J Drent, E Folmer \& M van Stralen (2012) Ontwikkeling van schelpdierbestanden op de droogvallende platen van de Waddenzee. De Levende Natuur 113(3): 83-88.

Troost, K, KJ Perdon, J Jol, M van Asch \& D van den Ende (2015) Bestanden van mesheften, halfgeknotte strandschelpen en andere schelpdieren in de Nederlandse kustwateren in 2015. IMARES onderdeel van Wageningen UR, rapport C143/15.

Van Asch, M, EBM Brummelhuis, D van den Ende, K Troost \& C van Zweeden (2018) Het kokkelbestand in de Nederlandse kustwateren in 2018. Wageningen Marine Research, Centrum voor Visserij Onderzoek. CVO rapport 18.011.

Van den Ende, D, K Troost, M van Asch, KJ Perdon \& C van Zweeden (2018) Mosselbanken en oesterbanken op droogvallende platen in de Nederlandse kustwateren in 2018: bestand en arealen. Wageningen Marine Research, Centrum voor Visserij Onderzoek. CVO rapport 18.023.

Van Stralen, M., K. Troost \& D. van den Ende (2018a) Inventarisatie van het sublitorale wilde mosselbestand in de westelijke Waddenzee in het najaar van 2018. Bureau MarinX, Scharendijke, rapport 2018.184.

Van Stralen, M., D. van den Ende \& K. Troost (2018b) Inventarisatie van het sublitorale wilde mosselbestand in de westelijke Waddenzee in het voorjaar van 2018. Bureau MarinX, Scharendijke, rapport 2018.180.

Winter, AG, RLH Deits \& AE Hosoi (2012) Localized fluidization burrowing mechanics of Ensis directus. The Journal of Experimental Biology 215: 2072-2080. 


\section{Verantwoording}

Rapport Error! Reference source not found.

Projectnummer: 4318100230

Dit rapport is met grote zorgvuldigheid tot stand gekomen. De wetenschappelijke kwaliteit is intern getoetst door een collega-onderzoeker en het verantwoordelijk lid van het managementteam van Wageningen Marine Research

Akkoord:

Dr. Henrice Jansen

Onderzoeker

Handtekening:

Datum:

datum

Akkoord:

naam van het verantwoordelijk MT-lid /director als verantwoordelijk voor de inhoud

functie

Handtekening:

Datum:

datum 


\section{Bijlage 1. Geregistreerde soorten}

Tabel 2. Alle soorten die structureel geregistreerd worden in de sublitorale mosselzaadinventarisatie. Mosselen, kokkels, zeesterren en zeepokken zijn gedurende de gehele periode geregistreerd. Overige schelpdieren zijn geregistreerd vanaf 1993 met uitzondering van 1995 en 1996. Overige stekelhuidigen zijn vóór 2001 incidenteel geregistreerd en structureel vanaf 2001. Overige geleedpotigen (waaronder alle soorten krabben) zijn geregistreerd vanaf 2001.

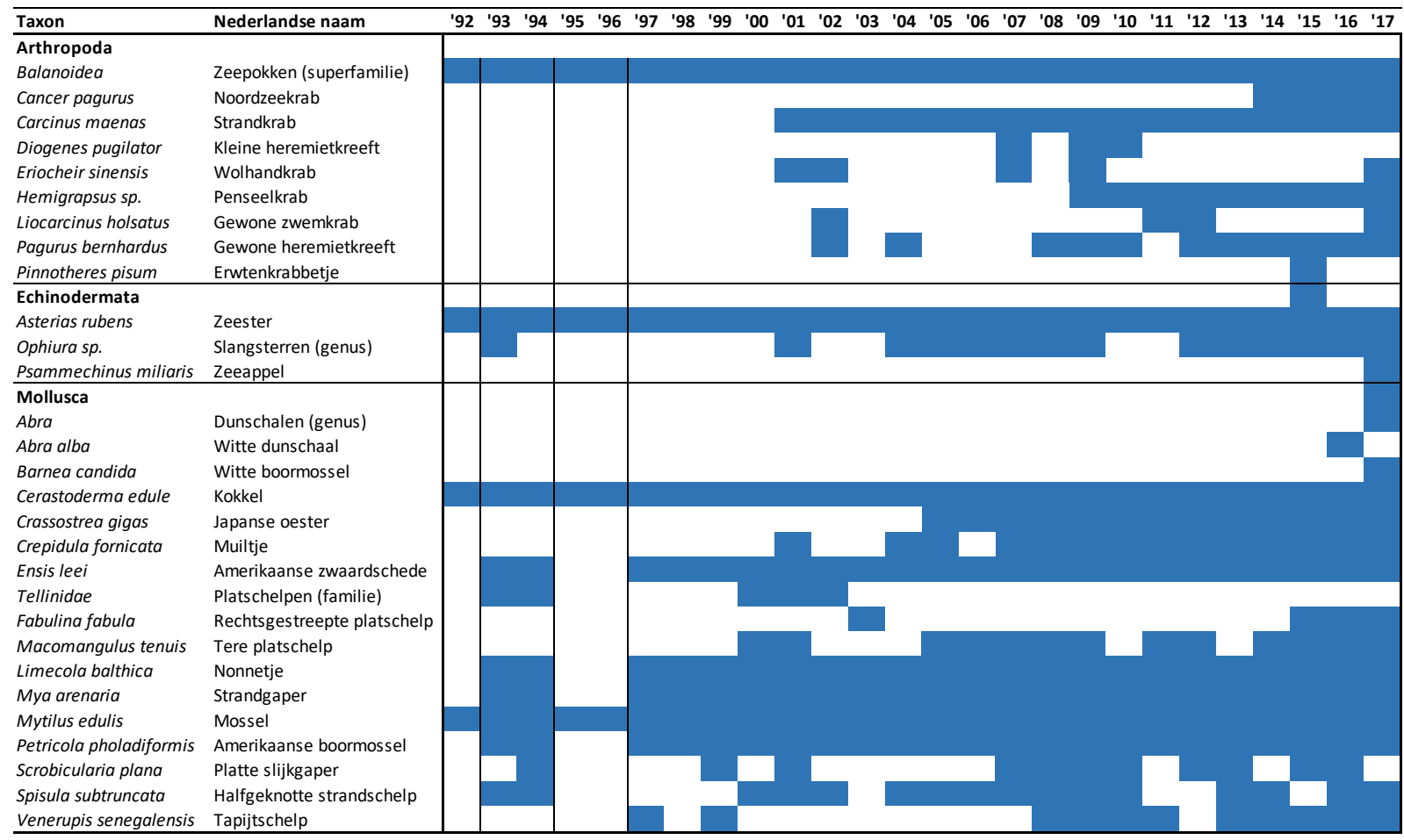


Wageningen Marine Research

T: $+31(0) 317480900$

E: marine-research@wur.nl

www.wur.nl/marine-research

Visitors address

- Ankerpark 271781 AG Den Helder

- Korringaweg 7, 4401 NT Yerseke

- Haringkade 1, 1976 CP IJmuiden
Wageningen Marine Research is the Netherlands research institute established to provide the scientific support that is essential for developing policies and innovation in respect of the marine environment, fishery activities, aquaculture and the maritime sector.

Wageningen University \& Research is specialised in the domain of healthy food and living environment.

\section{The Wageningen Marine Research vision:}

'To explore the potential of marine nature to improve the quality of life.'

\section{The Wageningen Marine Research mission}

- To conduct research with the aim of acquiring knowledge and offering advice on the sustainable management and use of marine and coastal areas.

- Wageningen Marine Research is an independent, leading scientific research institute.

Wageningen Marine Research is part of the international knowledge organisation Wageningen UR (University \& Research centre). Within Wageningen UR, nine specialised research institutes of Stichting Wageningen Research (a Foundation) have joined forces with Wageningen University to help answer the most important questions in the domain of healthy food and living environment. 